\title{
GCU
}

Glasgow Caledonian

University

University for the Common Good

\section{Multiple large shareholders, excess leverage and tunneling: evidence from an emerging market}

Boateng, Agyenim; Huang, Wei

Published in:

Corporate Governance

DOI:

$10.1111 /$ corg. 12184

Publication date:

2017

Document Version

Author accepted manuscript

Link to publication in ResearchOnline

Citation for published version (Harvard):

Boateng, A \& Huang, W 2017, 'Multiple large shareholders, excess leverage and tunneling: evidence from an emerging market', Corporate Governance, vol. 25, no. 1, pp. 58-74. https://doi.org/10.1111/corg.12184

\section{General rights}

Copyright and moral rights for the publications made accessible in the public portal are retained by the authors and/or other copyright owners and it is a condition of accessing publications that users recognise and abide by the legal requirements associated with these rights.

Take down policy

If you believe that this document breaches copyright please view our takedown policy at https://edshare.gcu.ac.uk/id/eprint/5179 for details of how to contact us. 


\title{
Multiple Large Shareholders, Excess Leverage and Tunneling: \\ Evidence from an Emerging Market
}

\begin{abstract}
Manuscript Type: Empirical

Research Question/Issue: Past empirical efforts in corporate governance have examined the effects of large shareholders with the excess control rights on tunneling activities. However, no study has systematically investigated the effects of multiple large shareholders on excess leverage policies and tunneling in an emerging country environment where minority rights protection is weak. In this study, we examine the role of multiple large shareholders and the effects of control contestability of multiple large shareholders on firm excess leverage decision and tunneling by controlling shareholders.
\end{abstract}

Research Findings/Insights: Using a sample of 2,341 Chinese firms for the years 2001 to 2013, we document that the contestability of multiple non-controlling large shareholders relative to controlling shareholders reduces the adoption of excess leverage policies, tunneling and enhances capital investment. Another intriguing finding is that the government as a controlling shareholder exerts significant influence and reduces the monitoring effectiveness of multiple larger shareholders.

Theoretical/Academic Implications: By addressing the role of multiple large shareholders on excess leverage decisions, this study makes an important contribution to the corporate governance literature. We extend the recent developments in agency theory regarding the role of multiple large shareholders in constraining expropriation of controlling shareholders with excess control rights and their effect on firm leverage decisions. Our results support the theoretical models which indicate that the presence of multiple large shareholders is an important and efficient internal governance mechanism that mitigates a firm's agency costs, particularly, in an emerging market environment where corporate governance is weak and inadequate to curb tunneling problem.

JEL classification: G15; G34; G38

Keywords: Corporate Governance; Multiple Large Shareholders; Excess Leverage; Tunneling; 
Control and Cash flow Rights.

\section{INTRODUCTION}

One important aspect of the governance characteristics of a firm is the ownership concentration. The importance stems from the fact that concentrated ownership creates agency problems, affects the behaviour of shareholders with implications for firm value. In the context of emerging economies, systematic research evidence indicates that emerging country firms have concentrated ownership structures unlike firms in the United States which are widely dispersed (see La Porta et al., 1999; Dharwadkar et al., 2000; Morck et al., 2005; Kumar and Zattoni, 2014). Many firms across the globe, particularly those in East Asia, predominantly have single large shareholders who exercise ultimate control, despite owning few cash flow rights (Claessens et al., 2000; Faccio and Lang, 2002; Young et al., 2008). Researchers such as Pagono and Roell (1998); Laeven and Levine (2008) argue that ownership structure comprising shareholders with large stakes in the company can benefit minority shareholders by improving monitoring over managers. However, Casado et al. (2016); Li et al. (2015); Shleifer and Vishny (1997) note that, large shareholders can also be harmful and create principal-principal conflicts (i.e. goal incongruence among shareholder groups in a firm, particularly between the controlling and minority shareholders). For example, large shareholders with excess control rights provide large controlling shareholders with incentives to extract private benefits for themselves at the expense of other shareholders, popularly referred to as tunneling (Young et al., 2008). Recent corporate governance studies, such as Liu and Tian (2012) and Faccio et al. (2010) have therefore focused on the effects of ownership concentration involving large controlling shareholders on tunneling activities and firms' leverage decisions. The predominant research evidence is that emerging 
economy firms with excess control rights vested in the controlling shareholders use high excess leverage as a channel to place more resources at their disposal to facilitate tunneling activities (Claessens et al., 2000; Claessens et al., 2002; Faccio and Lang, 2002; Jiang et al., 2010; Liu and Tian, 2012; Paligorova and Xu, 2012; Qian and Yeung, 2015; Buchuk et al., 2014).

The prevalence and severity of tunneling activities, as measured through intercorporate loans, of controlling shareholder (Cheung et al., 2006; Peng et al., 2010), and the inadequacy of the existing laws to curb the problem are well documented in many emerging countries (see Jiang et al., 2010 and Buchuk et al., 2014 for review). Thus, it is not surprising that a number of studies have sought to explain the potential corporate governance role of multiple large shareholders in curbing the expropriations of controlling shareholders (Casado et al., 2016; Attig et al., 2008; Laeven and Levine, 2008; Maury and Pajuste, 2005). However, the notable contributions in recent literature have focused on the presence and effects of multiple (non-controlling) large shareholders with respect to two issues: the cost of capital and corporate valuation (see Attig et al., 2008; Laeven and Levine, 2008; Maury and Pajuste, 2005). To our knowledge, no study has systematically investigated the direct effects of multiple large shareholders on excess leverage decisions and the effect of their role in constraining the extraction of private benefits by controlling shareholders. However, it is argued that multiple large shareholders constitute the extent of ownership dispersal and their presence may engender control contestability relative to the controlling shareholders, a situation that may lead to efficient monitoring (Attig et al., 2013; Maury and Pajuste, 2005 and Pagano and Roell 1998). The theoretical view regarding the benefits of multiple large shareholders indicates that they play a vital monitoring role in curbing 
the extraction of private benefits (Attig et al., 2009; 2013). For example, Pagano and Roell (1998) note that multiple large shareholders increase the contestability of the largest shareholder's control and that they are more likely to reduce the potential to extract private benefits from the firm at the expense of minority shareholders.

This article departs from prior studies, which have either focused on the effects of multiple large shareholders on corporate value or the general economic benefits of multiple large shareholders, by examining the effects of multiple large shareholders on firms' excess leverage decisions and how their contestability relative to controlling shareholders may mitigate tunneling activities. Specifically, we attempt to answer the following question: Can the excess leverage policy often adopted as a vehicle for tunneling through intercorporate loans be alleviated by multiple (noncontrolling) large shareholders? We focus on excess leverage because prior studies such as Paligorova and Xu, (2012), Lin et al. (2011) and Qian and Yeung (2015) note that the adoption of excess leverage policies provides a primary vehicle for controlling shareholders with excess control to divert resources from the firm for their private benefit rather than investing in projects with positive net present value. Moreover, in an environment where corporate governance is weak, excess leverage is more likely to be used in a discretionary manner (Paligorova and $\mathrm{Xu}$, 2012; Luo et al., 2012).

China is selected for this study for two reasons. One, concentrated ownership, which is the root cause of principal-principal conflicts, is common among publicly traded companies in most Asian countries (Gedajlovic et al., 2004; Djankov et al., 2008). Moreover, ownership concentration in public companies is pronounced, and all Chinese listed firms have controlling 
shareholders and multiple non-controlling large shareholders (Jiang et al., 2010). Two, the poor market-based institutional framework for internal and external governance such as the weak nature of the board of directors, the ineffective market for corporate control and the weak legal system, which offers less institutional protection for minority shareholders and provides them with relatively few avenues for private enforcement, make tunneling a frequent occurrence ( $\mathrm{La}$ Porta et al., 2002; Allen et al., 2005; Cheung et al., 2006; Jiang et a., 2010; Qian and Yeung, 2015).

This study makes an important contribution to the corporate governance literature in the following way. We extend the recent literature regarding the role of multiple large shareholders in constraining expropriation of controlling shareholders with excess control rights and their effect on firm leverage decisions. In particular, we provide one of the first attempts to examine the effects of contestability of multiple large shareholders on excess leverage decisions and tunneling activities, thereby extending the evidence of Liu and Tian (2012) and Jiang et al. (2010) who examined the role of controlling shareholders on excess leverage and tunneling through intercorporate loans. We document that the contestability of multiple (non-controlling) large shareholders relative to controlling shareholders reduces the adoption of excess leverage and tunneling. Our findings appear robust in all models after considering excess control rights and the type of controlling shareholder. Our results support the theoretical models, which contend that the presence of multiple large shareholders is an important internal governance mechanism that mitigates a firm's agency costs, particularly, in an emerging market environment where corporate governance is weak and inadequate to curb tunneling problem. 
This paper is structured as follows. Section 2 presents background information on ownership structure in China, reviews the related literature and develops the hypotheses of the study. Section 3 presents the data and methodology of the study, and this is followed by an analysis and discussions of our results in section 4. Section 5 presents the paper's conclusions.

\section{LITERATURE REVIEW AND HYPOTHESES DEVELOPMENT}

\section{Firm Ownership Structure in China}

Prior to the inception of enterprise reforms in the mid-1980s, state ownership was the main form of firm ownership in China. The reforms started gradually and accelerated in the 1990s, following the establishment of the Shanghai and Shenzhen Stock Exchanges in 1990 and 1991. The stock markets facilitated a massive privatization of state owned enterprises (SOEs) in China with the aim of revitalizing the non-performing SOEs (Sun et al., 2002; Sun and Tong, 2003). However, privatization in China has not led to the complete ownership of firm assets by private investors, and thus, the state and its agencies still retain a substantial proportion of firms' ownership in China. Typically, a listed company in China has a mixed ownership structure that is concentrated in the hands of three dominant ownership groups of shareholders - the state, a legal person, and tradable A and B shares, which account for approximately one-third of all listed companies around the year 2000 (Sun and Tong, 2003). Ownership concentration of firms appears high in China despite the split-share reforms to improve liquidity and diversify the shareholders' base in China. According to Jiang and Kim (2015), shareholding by the largest shareholder in China, on average, accounts for over one-third of the total number of shares. Researchers such as Claessens et al. (2002) note that concentrated ownership allows dominant and controlling shareholders to use leverage without diluting their control over the firm to enable 
tunneling. Recent studies in China by Liu and Tian (2010) and Qian and Yeung (2015) have provided some support and have documented the principal-principal conflict in leverage decisions that results from concentrated ownership and a weak banking system.

\section{Related Literature}

Prior literature in finance and corporate governance have predominantly applied the traditional Jensen and Meckling (1976) conceptualization of principal-agent conflicts to explain a firm's financing decisions and value (Lins, 2003; Zweiebel, 1996; Berger et al., 1997; Chan et al., 2014). Increasingly, researchers have recognized that listed firms in emerging countries are not widely held but rather are controlled by dominant shareholders (La Porta et al., 1999; Wright et al., 2005; Young et al., 2008; Kumar and Zattoni, 2011). Researchers such as Dharwadkar et al. (2000), Morck et al. (2005) and Young et al. (2008) note that concentrated ownership in emerging economies coupled with the absence of effective external governance mechanisms leads to frequent principal-principal conflicts where controlling shareholders with excess control rights expropriate the interests of other shareholders. Forms of expropriation include transferring assets to private holding at below market value and corporate expenditures on non-value creating activities that advance personal agenda ( $\mathrm{Su}$ et al., 2008). Intercorporate loans have been identified as one common channel of expropriation in China used by controlling shareholders to divert funds from publicly listed firms. For example, Jiang et al. (2010) showed that tens of billions in RMB are transferred from hundreds of Chinese firms by controlling shareholders in the form of "other receivables". Other receivables are loans found in the balance sheets of many Chinese firms and they constitute about $15.9 \%$ of the value of total tradable shares (Jiang et al., 2010). This study investigates this form of tunneling because intercorporate loans are traceable 
through public sources thereby overcoming the measurement problems associated with the varied nature of tunneling activities (Jiang et al., 2010). Moreover, Jiang et al. (2010) found negative and significant economic consequences for the shareholders with high "other receivables" balances and indicate that such firms have worse future operating performance and are more likely to experience financial distress. This is because excess leverage in these firms provides the resources for intercorporate loans and more importantly most of these loans do not accrue interests and where they do, neither interest nor the principal are ever paid (Jiang et al., 2010). In addition, higher leverage is associated with higher risk and higher cost of capital and heightens chances of financial distress (Modigliani and Miller, 1958). However, it should be pointed out that the chance of Chinese listed firms going bankrupt is rare due to the state ownership of most firms (Sun and Tong, 2003) and the potential adverse implications for social and political stability of China. Consequently, major state owned banks (the Big 5) which accumulated some huge non-performing loans in the past have had them either written off or transferred to Asset Management Companies created by the state. While steps have been taken to improve the monitoring of credit by the banks, credit pressures and monitoring system remain weak due to state interferences in credit allocation by banks (Poncet et al., 2010; Cull et al., 2015).

In an attempt to address the tunneling activities of controlling shareholders, recent empirical efforts have concentrated on the governance role of multiple shareholders. Among the prominent studies that have explored the role of multiple large shareholders in corporate governance and their impact on firm value are Zwiebel (1995), Pagano and Roell (1998), Gomes and Novaes (2005), Maury and Pajuste (2005), Laeven and Levine (2008), Attig et al. (2009) and Attig et al. (2013). The above studies offer two competing perspectives to explain the role of multiple large 
shareholders. At one end of the spectrum, it is argued that multiple large shareholders play a pivotal monitoring role in curbing the extraction of private benefits (Bennedsen and Wolfenzon, 2000). On the other hand, Zwiebel (1995) and Gomes and Novaes (2005) raise doubt about the efficient monitoring role of multiple large shareholders, and their model contends that the concentration of control in the hands of one large investor offers better protection for minority shareholders. However, the predominant view in the literature suggests that multiple large shareholders play a valuable corporate governance role in firms that operate in weak legal environments. For example, Laeven and Levine (2008), Maury and Pajuste (2005), Attig et al. (2013), Young et al. (2008), Guedhami and Misha (2009) and Mishra (2011) have documented that multiple large shareholders engage in efficient monitoring and can reduce the expropriation of private benefits. These studies argue that multiple large shareholders are likely to participate in firm governance because of high exit costs, such as price effects, transaction costs, tax timing and rebalancing costs that render the sale of large block holdings increasingly unattractive, thereby making monitoring desirable. However, prior studies examining excess leverage and tunneling activities have focused on controlling shareholders and ignored the potential role of multiple shareholders (see Attig, Ghoul and Guedhami, 2009; Faccio et al., 2010; Jiang et al., 2010; Liu and Tian, 2012; Qian and Yeung, 2015). If these studies mention multiple large shareholders in relation to excess leverage and tunneling activities, it is done only casually. In this paper, we extend this line of research by examining the effects of multiple large shareholders on value-destroying policies, such as excess leverage and tunneling activities of controlling shareholders, to which little attention has been given. Two hypotheses are formulated to test the effects of multiple large shareholders and excess leverage and tunneling through intercorporate loans. 


\section{Hypothesis Development}

\section{Contestability and Excess Leverage Decisions}

Recent theoretical development and empirical studies in corporate governance have examined settings with more than one large blockholder, which allow some level of contestability to emerge on the basis of coalitions formed among the large shareholders (Bennedsen and Wolfenzen, 2000; Laeven and Levine, 2008; Gutierrez and Pombo, 2009). Thus, according to the alignment-of-interests hypothesis, other large shareholders may collude with the largest shareholder to exploit the private benefits of control (Kahn and Winton, 1998). While coalition can be formed among any of large shareholders, coalition between the controlling shareholder and the second largest shareholder in emerging countries appears rare for the following reasons. First, controlling shareholders in emerging countries such as China, on average, hold over onethird of the total number of shares (Jiang and Kim, 2015). Second, emerging countries including China have weak legal protection for minority shareholders and governance mechanisms such as market for corporate control and independent director system do not work effectively (Andersen and Reeb, 2004; Hu, Tam and Tan, 2010; Peng and Jiang, 2010; Luo et al., 2012). Consequently, coalition between the controlling shareholder and second large shareholders leave other multiple large shareholders with no option but to divest their shareholdings if investors are rational as posited by finance theory. This is because they have virtually no protection under the emerging market governance system compared with the governance system found in advanced countries. 
Indeed, Zhang et al. (2014:442) note that "controlling shareholders in China generally enjoy absolute control over firms”. Friedman et al. (2003); Su et al. (2008); Jameson et al. (2014) echo similar views and reported that, controlling shareholders are more prone to extract private rent and maximize their utility at the expense of minority shareholders in emerging country setting. Against this backdrop, scholars such as Bennedsen and Wolfenzen (2000); Gomes and Novaes (2005); Jiang and Peng (2011); Maury and Pajuste (2005); Gutierrez and Pombo (2009) have emphasized the use of the multiple large shareholders structure as an important and most efficient means to curb tunneling activities of controlling shareholders in emerging economies For example, Bennedsen and Wolfenzon (2000) indicate that multiple large shareholders can monitor controlling shareholders by competing for control (contestability). Attig et al. (2013) argue that the sheer size of ownership of multiple large shareholders confers bargaining power, reduces the free-rider problem caused by widely dispersed corporate ownership and makes monitoring a necessity to protect their investments. Consistent with the theoretical model of Bennedsen and Wolfenzen (2000), we argue that if the combined stakes of multiple large shareholders are comparable to the stake of the controlling shareholder, control contestability heightens, resulting in competition for corporate control and incentives for efficient monitoring. The studies of Lehman and Weigand (2000), Maury and Pajuste (2005), Laeven and Levine (2008); Attig et al. (2009) and Luo et al. (2012) have rendered support by indicating that the presence of other multiple large shareholders with relative significant voting power is associated to a valuable corporate governance role.

Regarding leverage decisions, Faccio et al. (2010); Paligorova and Xu (2012) show that leverage in countries with a weak legal system enables controlling shareholders to deploy borrowed 
resources for their own benefits without bearing fully the financial distress cost. To the extent that leverage affects firm value and its riskiness, we expect that debt may facilitate expropriation by controlling shareholders as long as the firms face no financial distress (see Paligorova and $\mathrm{Xu}$, 2012). In the context of China, the use of debt becomes an important vehicle for expropriation as the central and the local governments rarely allow firms to go bankrupt due to political and social stability concerns and the dominance of state ownership of most of the Chinese listed firms (see Sun and Tong, 2003). Accordingly, we put forward the following hypotheses:

Hypothesis 1: The contestability of multiple (non-controlling) large shareholders will negatively influence firms' excess leverage, all else being equal.

\section{Contestability, Excess Leverage and Tunneling}

Liu and Tian (2012) investigate the tunneling activities of Chinese firms by linking excess control rights and excess leverage to intercorporate loans, which is one of the direct measures of tunneling by controlling shareholders (see Jiang et al., 2010). Qian and Yeung (2015) further document that easier access to bank loans also leads to tunneling through intercorporate loans. These two recent studies suggest that controlling shareholders with excess control rights adopt an excess leverage policy not to invest but to facilitate tunneling. Faccio et al. (2010) conjecture that multiple large shareholders can constrain the controlling shareholders from adopting valuedestroying policies, such as excess leverage and tunneling, particularly when the legal protection for minority shareholders is weak. Benedsen and Wolfenzen (2000) also suggest that the contestability of multiple large shareholders relative to controlling shareholders tends to lower the firm's excess leverage and tunneling due to the high risk of control contestability. We argue that multiple large shareholders may not only serve as an internal corporate governance 
mechanism by performing an efficient monitoring role but that they may have the capacity to compete for control and moderate the link between excess control and tunneling. Therefore, we contend that the interaction between controlling the excess control rights of a shareholder and the contestability of multiple (non-controlling) large shareholders should mitigate the tunneling activities of the controlling shareholders. Thus, we put forward the following hypothesis:

Hypothesis 2: The contestability of multiple (non-controlling) large shareholders moderates the link between controlling shareholder excess control rights and tunneling.

\section{DATA AND METHODS}

We collect our data from the China Stock Market and Accounting Research (CSMAR) database. Our sample includes 2,341 listed non-financial firms for the years 2001 to 2013 and 15,790 firmyear observations for which data are available for all the variables we require for the analysis. We examine financial leverage from the perspective of corporate governance and tunneling. To this end, our sample period begins in 2001 when The Code for Corporate Governance was issued by the China Securities Regulatory Commission (CSRC). Consistent with the extant work in this area, financial sector firms are excluded due to their special capital components.

We calculate the percentage measure of financial leverage as:

Leverage $=100 *$ Book value of Debt $/($ Market Capitalization + Book value of Debt $)$

Similar to Liu and Tian (2012), we estimate the industry median adjusted financial leverage ratio as the measure of excess leverage, denoted as EX_Leverage ${ }^{\mathrm{i}}$. 
To test Hypothesis H1, we adopt a dynamic panel-data model that includes firm fixed-effects $\alpha_{i}$ and a disturbance term $\varepsilon_{i t}$ as follows:

$$
\text { EX_Leverage }_{\mathrm{it}}=\alpha_{i}+\beta \text { Contest }_{\mathrm{it}}+\eta \text { EX_Leverage }_{\mathrm{it}-1}+\gamma \mathrm{X}_{\mathrm{it}}+\varepsilon_{\mathrm{it}} \text {. }
$$

To simultaneously account for the endogeneity of ownership and control, leverage, and corporate governance, we use the two-step Arellano and Bover (1995)/Blundell and Bond (1998) dynamic panel-data system estimator with Windmeijer (2005) bias-corrected robust standard errors in all models. In particular, we first-difference all variables and estimate the model by GMM and use lagged values of the governance variables, contestability variables, and other firm characteristics as instruments. Wintoki et al. (2012) provide strong evidence that the instruments associated with a dynamic GMM approach are valid and powerful for corporate governance research. We test for second order serial correlations AR(2) and Sargan test of overidentifying restrictions for validity of our model and the GMM instruments.

The independent variable Contest ${ }_{\mathrm{it}}$ refers to a number of ownership and control variables we adopt as proxies for contestability of multiple non-controlling large shareholders with the controlling shareholder. ${ }^{\text {ii }}$ The definitions of cash flows rights and control rights of the controlling shareholder follow Claessens et al. (2002), Faccio and Lang (2002), and Liu and Tian (2012) where cash flow rights are measured by the sum of the products of the proportion of ownership along the control chains, and the control rights are measured by the minimum proportion of ownership along the control chains. Data on the controlling shareholder's cash flow rights (CF_Rights1) and control rights (CN_Rights1) are collected from CSMAR. To consider the 
multiple non-controlling large shareholders influence on excess financial leverage, we examine the second-tier largest shareholders collective shareholdings. We denote CF_Rights2 as the total shareholding percentage of the $2^{\text {nd }}$ and $3^{\text {rd }}$ largest shareholders and CF_Rights9 as the total shareholding percentage of the $2^{\text {nd }}$ to $10^{\text {th }}$ largest shareholders. Finally, we calculate four proxy measures of contestability: (1) CF_Contest2, cash flow competition of the $2^{\text {nd }}$ and $3^{\text {rd }}$ largest shareholders calculated as the ratio of CF_Rights2 to CF_Rights1; (2) CF_Contest9, cash flow competition of the $2^{\text {nd }}$ to $10^{\text {th }}$ largest shareholders calculated as the ratio of CF_Rights9 to CF_Rights1; (3) CN_Contest2, control competition of the $2^{\text {nd }}$ and $3^{\text {rd }}$ largest shareholders calculated as the ratio of CF_Rights2 to CN_Rights1; and (4) CN_Contest9, control competition of the $2^{\text {nd }}$ to $10^{\text {th }}$ largest shareholders calculated as the ratio of CF_Rights9 to CN_Rights 1. ii

Consistent with the prior studies (Jiang et al., 2010; Liu and Tian, 2012; Jiang et al, 2015), $\mathrm{X}_{\mathrm{it}}$ denotes a group of control variables that includes the log of market capitalization of all common shares in RMB (Market CAP); the return on assets (ROA); GOV, a dummy that equals 1 if the firm is under the control of the government or a government agency, and 0 otherwise; NT_Share, the percentage of shares that are non-tradable (state shares and legal person shares); EX_PAY, the excess executive cash compensation as a measure of managerial power, calculated as the regression error from an OLS regression of the average top 3 executive cash compensations per person on the Market_CAP, ROA, GOV, and the industry dummies; CEO Duality, a dummy that equals 1 if the CEO is also the chair of the board, and 0 otherwise; TAX, the corporate tax rate; CF/SALES, the operating cash flow to sales ratio; and Board_IND, the percentage of independent board members. Appendix A provides a detailed description of the variables. 
To test hypothesis 2, we follow Jiang et al. (2010), Liu and Tian (2012), and Qian and Yeung (2015) and use "other receivables" as a proxy for intercorporate loan tunneling. We adopt a Tobit model as follows:

INC_LOAN $_{\text {it }}=\alpha+\beta_{1}$ EX_Leverage $_{\mathrm{it}-1}+\beta_{2}$ DEXCON $_{\mathrm{it}}+\beta_{3}$ Contest $_{\mathrm{it}}+\beta_{4}$ DEXCON $_{\mathrm{it}} *$ Contest $_{\text {it }}+\delta$ Controls $_{\mathrm{it}}+\varepsilon_{\mathrm{it}}$

The dependent variable INC_LOAN $i$ it the balance of the other receivables account scaled by total assets. We choose a Tobit model as this dependent variable is left censoring. As excess leverage is endogenous, we include its 1-period lagged variable EX_Leverage $\mathrm{it}_{\mathrm{it}-1}$. The variable DEXCON $_{i t}$ is a dummy for excess control rights of the controlling shareholder that equals 1 if its control rights exceed its cash flow rights, and 0 otherwise. The interaction DEXCON ${ }_{\mathrm{it}} *$ Contest $_{\mathrm{it}}$ shows the influence of multiple large shareholders on the link between excess control rights of the controlling shareholder and tunneling. As control variables, we include the government control dummy (GOV), the percentage of non-tradable shares (NT_Share), CEO duality dummy (CEO Duality), and board independence measure (Board_IND) as corporate governance affects tunneling (Jiang et al., 2010; Liu and Tian, 2012; Qian and Yeung, 2014). We also include the corporate tax rate (TAX) and ROA due to tax motivated income shifting (Shevlin et al., 2012) and increased tunneling incentives when firms are more profitable (Peng et al., 2012). Finally, we include Market_CAP for size effect.

\section{ANALYSIS AND DISCUSSIONS OF RESULTS}

\section{Univariate Analysis}


Table 1 reports the summary statistics of our sample. The average financial leverage for the sample is $29 \%$. Industry median adjusted excess leverage has a mean of $1.23 \%$ and ranges from $33.4 \%$ to $51.4 \%$. The controlling shareholders, on average, hold approximately $37 \%$ of the shares and $40 \%$ of the control rights, suggesting they have excess control rights (Liu and Tian, 2012). The results support similar observations made by Jiang and Kim (2015), thus indicating that the largest shareholders in China hold between a $36 \%$ and $45 \%$ stake in Chinese listed firms. The second-tier largest shareholders' collective shareholdings are, on average, between 13\% and 21\% for CF_Rights2 and CF_Rights9, respectively. We also notice that, on average, these collective shareholdings are lower than the cash flow rights and control rights of the controlling shareholder, as indicated by the contestability proxy measures. The average growth rate of fixed assets is $26 \%$. Intercorporate loan tunneling, as measured by INC_LOAN, is, on average, $2.56 \%$ for our sample, but it is left censoring to zero. Finally, we notice that half of the firm-year observations are government controlled.

(Insert Table 1 about here)

Table 2 presents the correlations matrix of the variables. We observe that these univariate relations suggest that the controlling shareholders' cash rights and control rights are generally positively associated with financial leverage and excess financial leverage even though the correlations are near zero. The collective shareholdings of the non-controlling block holders and their contestability proxies are negatively associated with financial leverage and excess financial leverage. We further note that the correlations among the independent variables in our model are low, which suggests that multicollinearity is not a problem in this study. We conclude that the 
univariate analysis presented in Table 2 is consistent with our hypotheses, and thus, we proceed to explore these relationships in properly controlled regression models.

(Insert Table 2 about here)

\section{Regression Results}

\section{Baseline Tests}

Before testing our main hypotheses, we conduct a number of baseline tests on the connections between main ownership and the control variables and excess leverage. Table 3 reports the results of the baseline tests. Consistent with our expectation, we find that the percentage of cash flow rights in Models 1 and $2\left(\mathrm{CF}_{-}\right.$Rights $\left.1: \beta=.093 ; \beta=.103, \mathrm{p}<.05\right)$ and control rights in Models 3 and 4 (CN_Rights1: $\beta=.125, \beta=.124, \mathrm{p}<.05)$ of the controlling shareholder are positively and significantly related to a firm's excess leverage. The results suggest that the structural power of the controlling shareholder increases excessive financial risk taking. In these models, we successively include the percentage of collective shareholdings by other multiple large shareholders, $C F \_$Rights2 and CF_Rights9 representing the total shareholdings of the $2^{\text {nd }}$ and the $3^{\text {rd }}$ largest shareholders and the total shareholdings of the $2^{\text {nd }}$ to the $10^{\text {th }}$ largest shareholders, respectively. We find that the coefficients of CF_Rights2 in Models 1 and $3(\beta=-$ 0.156, $\beta=-0.211, \mathrm{p}<.05)$ and CF_Rights9 in Models 2 and $4(\beta=-0.105, \mathrm{p}<0.05 ; \beta=0.144$, $\mathrm{p}<0.01)$ are negatively and significantly associated with firm excess leverage. The results indicate that the presence of multiple large shareholders reduces excess leverage, thereby suggesting that the presence of multiple large shareholders has the opposite effect and restrains the controlling shareholder from taking excessive financial risk. Our results are robust with the inclusion of a number of control variables that have been used in prior studies as potential factors 
influencing leverage decisions. The control variables suggest that managerial power (or excess executive pay), government control, CEO duality, and board independence significantly increase excess leverage. On the other hand, size, tax, return on assets, and operating cash flows significantly decrease excess leverage.

\section{(Insert Table 3 here)}

\section{Contestability, Ownership Type and Excess Leverage Decisions}

Regressions in respect of Table 4 test our Hypothesis 1 regarding the influence of multiple large shareholders on sample firms' excess leverage. In Models 1, 2, 5 and 6, we test cash flow rights, and in Models 3, 4, 7 and 8, we test the control rights contestability of multiple large shareholders relative to the controlling shareholders. In Models 1 to 4, we find that all four proxy measures of contestability are negatively and significantly related to excess leverage, thereby providing strong support for Hypothesis 1 . The results suggest that contestability leads to the balance of power between multiple large shareholders and controlling shareholders and that it provides an efficient monitoring role by constraining excess leverage.

We consider the effects of government and private investors as controlling shareholders on excess leverage. Specifically, we focus on whether the type of controlling shareholder alters the monitoring role of multiple large shareholders with respect to the adoption of excess leverage. It may be conjectured that the type of controlling shareholder may affect the monitoring role and the contestability of the second-tier block holders due to the divergence of goals between government ownership and private ownership and the relative bargaining power of the state agency and private investors in firm decision making (Sun and Tong, 2003; Firth et al., 2010; 
Jiang et al., 2010). We further incorporate the interaction variables for contestability measures and the government control dummy (GOV) in Models 5 to 8 .

Models 5 and 6 of Table 4 report the interaction between cash flow contestability (CF_Contest2 and CF_Contest9) and the government as the controlling shareholder (GOV). We find positive and significant coefficients for the interactive variables: CF_Contest $2 *$ GOV $(\beta=14.358 ; p<.01)$ and CF_Contest $9 *$ GOV $(\beta=10.172, \mathrm{p}<0.01)$, thus suggesting that the government as a controlling shareholder exerts significant influence by reducing the monitoring effectiveness of multiple larger shareholders. In short, these results suggest that the moderating effect of government control appears stronger than the monitoring power of multiple large shareholders. In Models 7 and 8, the interaction variables between control rights contestability measures and government control (CN_Contest $2 * G O V: \beta=9.394, p<.01$ and CN_Contest $9 * G O V: \beta=8.006$; $\mathrm{p}<0.01)$ are significant and positive, but the totals of the coefficients on contestability variables given government control remain significantly negative. These results indicate that government associated controlling shareholders potentially nullify the monitoring role of multiple large shareholders. As control rights provide more reliable reflections of shareholder influence on firm decisions, we conclude that multiple large shareholders restrain excess leverage irrespective of the type of corporate control. The results are robust after controlling for managerial power (or excess executive pay), government control, CEO duality, board independence, size, tax, return on assets, split-share reforms and operating cash flows.

(Insert Table 4 about here) 


\section{Sub-Sample Analysis}

To further explore the conditions under which competition and MLS monitoring will be stronger, thereby reducing the likelihood of coalition with the first controller, we carried out two sets of sub-sample analysis based on the nature of controlling shareholder and level of leverage of the sample firms. The results are reported in Table 5. Panel A of Table 5 reports the regression results using sub-samples partitioned according to the nature of the controlling shareholders (i.e. SOE and POE). In models 1-4, we document that when the controlling shareholder is government, multiple large shareholders appear to have insignificant or weak influence on excess leverage decisions. The results confirm our earlier findings in Table 4 indicating that multiple large shareholders tend to have less influence over firm leverage decisions when government is a controlling shareholder. One plausible explanation may be that Chinese government as a controlling shareholder enjoys absolute control over firms and can interfere in the credit allocation from the state-owned banks, thereby leaving multiple shareholders with little or no influence. This explanation appears consistent with the conclusion drawn by Cull et al. (2015) and Poncet et al. (2010) who found that credit allocation in China is driven by government intervention through state-owned banks which give preferential treatment to state owned enterprises (SOEs) compared to private owned enterprises (POEs). The implication here is that the sheer power and influence of government as a controlling shareholder reduces the chances of government forming coalition with other multiple shareholders in pursuance of goals important for the state. In contrast, in models 5-8 examining the effects POEs as controlling shareholder, we find strong evidence of significant and negative influence of multiple large shareholders on firm excess leverage. Control competition or multiple large shareholder monitoring appears to be more prevalent when firm controlling shareholders are POEs. 
(Insert Table 5 about here)

Panel B of Table 5 reports the effects of the multiple large shareholders on the level of leverage. It may be argued that for low leveraged firms, controlling shareholders may have relatively little avenues to expropriate resources for their private benefit. Consequently, multiple large shareholders may not engage seriously in the monitoring role to reduce expropriation by controlling shareholder. We partitioned the excess leverage into low and high leverage. Our regression results indicate a significant and negative impact on excess leverage irrespective of whether the leverage is low or high. Our results appear unequivocal and consistent in almost all the regression models supporting the contention that multiple large shareholders predominantly engage in efficient monitoring to protect them against expropriation in emerging market environment where legal protection and other governance mechanisms appear weak. The results render some strong support for the conclusions drawn by Bennedsen and Wolfenzen (2000); Gomes and Novaes (2005); Jiang and Peng (2011); Maury and Pajuste (2005; Gutierrez and Pombo (2009) who note that multiple large shareholder structure has become an important and viable means to solve principal-principal conflict in emerging economies.

In Table 6, we further analyze the effects of controlling shareholders' excess control rights and contestability of multiple large shareholders on excess leverage. Models 1, 2 and 3 of the table report the impacts of excess control rights on excess leverage. We find the excess control rights, $\operatorname{DEXCON}(\beta=3.323, \beta=11.606, \beta=8.455 ; \mathrm{P}<0.01)$, are positively and significantly related to 
excess leverage, thus implying that the controlling shareholders with excess control rights adopt high excess leverage policy. These findings are consistent with the conclusion drawn by Faccio et al. (2010) and Liu and Tian (2012). In Models 2 and 3, we consider multiple large shareholder control contestability, CN_Contest2 $(\beta=-5.526, \mathrm{p}<0.05)$ and CN_Contest9 $(\beta=-4.533, \mathrm{p}<.01)$. We find the control contestability proxies to be negatively and significantly related to excess leverage. We probe further the influence of the interaction of controlling shareholders with excess control and multiple large shareholder contestability on excess leverage. The interaction between the excess control dummy and contestability measures appear to have negative coefficients in Models 2 and 3, suggesting that the interaction has a negative influence that appears to be significant $\left(\mathrm{DEXCON}{ }^{*} \mathrm{CN} \_\right.$Contest $\left.2: \beta=-12.365 ; \mathrm{p}<.05\right)$ in Model 2 . The results suggest that control contestability between multiple large shareholders and controlling shareholders tends to moderate the adoption of high excess leverage.

(Insert Table 6 about here)

\section{Contestability and Tunneling through Intercorporate Loans}

With respect to Hypothesis 2, we consider the role of multiple large shareholders in the link between controlling shareholder excess control rights and tunneling through intercorporate loans measured by the balance of the other receivables account scaled by total assets and denoted as INC_LOAN (Jiang et al. 2010). The test results are presented in Table 7. We adopt Tobit regressions as the dependent variable INC_LOAN, which is left censored. As excess leverage is endogenous, we use its 1-period lagged value (L.EX_Leverage) as the dependent variable. Models 1 through 4 of the table show a positive and significant relationship between 
L.EX_Leverage and INC_LOAN. Consistent with the findings of Liu and Tian (2012), our results indicate that the excess leverage is associated with tunneling through intercorporate loans. Our main interest is to examine the effects of multiple large shareholders on the link between controlling shareholder excess control rights and tunneling. Consequently, we introduce four interaction terms between the controlling shareholder excess control rights dummy (DEXCON) and the multiple large shareholder contestability variables.

(Insert Table 7 here)

The regression results consistently indicate that these interaction terms are negatively and significantly related to intercorporate loans (INC_LOAN), thus suggesting that multiple large shareholders constrain firms' controlling shareholders from tunneling through intercorporate loans. The results provide unequivocal support for Hypothesis 2, and they imply that multiple large shareholders constitute an important internal corporate governance mechanism and mitigate conflict of interest between the controlling shareholders and minority interests. Our results support, in general, the theoretical models of Benedsen and Wolfenzen (2000) and Pagano and Roell (2005), who concluded that the presence of other multiple large shareholders reduces agency costs. Despite the interesting findings, it is pertinent to point out that while the coefficients for the interaction between excess control rights and the multiple large shareholder contestability variables are negative, their constituent variables are positive. Perhaps the results of the constituent variables may also be explained by the institutional environment in emerging 
countries which makes it less likely for coalition contract between controlling shareholder due to the enormous power, the controlling shareholders often hold in the firm. Another plausible explanation may be that the monitoring role of multiple large shareholders tends to be more vigorous in the presence of excess control power of the controlling shareholders.

\section{Contestability and Capital Investment}

Our results indicate that cash flow and control rights of the controlling shareholder are positively and significantly associated with a firm's excess leverage while contestability of multiple large shareholders relative to the controlling shareholder mitigates tunneling. In the light of the findings of Liu and Tian (2012) which documented that excess control rights of controlling shareholders facilitate intercorporate loans and reduce capital investment in China, we explore further the influence of multiple large shareholders contestability on firm capital investment. The regression results are reported in Table 8 .

(Insert Table 8 here)

Our results in models 1-4 suggest that the excess leverage have negative coefficients which are significant indicating that excess leverage is inversely related to capital investment. Another interesting finding relates to the interaction between excess control and contestability measures. Our results show that the interaction between excess control and contestability measures are positive and significant in models 1,2 and 4 suggesting that control contestability between multiple large shareholders and controlling shareholders tends to increase capital investment of the sample firms. Our results confirm the notion that multiple large shareholders perform a vital monitoring role and can compensate for the poor legal protection for minorities (Berglof and 
Pajuste, 2003; Bennedsen and Wolfenzen, 2000; Gomes and Novaes (2005; Maury and Pajuste, 2005; Gutierrez and Pombo, 2009). However, we find that the coefficients of excess control rights (DEXCON) are negative and insignificant.

\section{CONCLUSION}

Past empirical evidence indicates that controlling shareholders with excess control rights engage in tunneling activities at the expense of minority shareholders. To the best of our knowledge, no study has systematically investigated the potential role of other large shareholders in constraining the controlling shareholders from extracting corporate resources for private benefits. To fill this gap, this study examines the role of multiple large shareholders and the effects of control contestability of multiple large shareholders on excess leverage decisions and controlling shareholder tunneling. We document that the contestability of multiple non-controlling large shareholders relative to controlling shareholders reduces the adoption of excess leverage, tunneling and enhances capital investment. Our findings appear robust in the models considering excess control rights and the type of controlling shareholder. We conclude that multiple large shareholders constitute an important internal corporate governance mechanism and that they reduce value-destroying excess leverage policy and mitigate tunneling activities of controlling shareholders in an environment where the corporate governance system is weak. Although, our findings appear robust after considering excess control rights and type of controlling shareholder, however, it is pertinent to note that, to some extent government as a controlling shareholder moderate the monitoring effectiveness of multiple large shareholders. 
Despite the significant contribution of this study, the limitation of this study is that, due to lack of data, we were not able to analyse the nature of the multiple large shareholders as to whether they were institutional investors or not. However, we believe that the nature of the multiple large shareholders may have a bearing on the extent of monitoring. We suggest that future studies investigate the nature and effects of non-controlling multiple large shareholders on excess leverage decisions and tunneling activities of controlling shareholders using cross-country data. Another interesting issue arising from the results of this study is that, we find no evidence of asymmetric effects between over-leveraged and under-leveraged firms. This suggests that the monitoring role of multiple large shareholders leads to a reduction in a firm's leverage irrespective of whether the level of leverage is higher or lower than the industry median, implying that under-leveraged firms may be more under-leveraged. While this issue is beyond the scope of the present paper, it opens an avenue for further research. We suggest that future research should investigate the effects of multiple large shareholders on over-leveraged and under-leveraged firms and the extent to which the multiple large shareholders impact on underleveraged firms' capital investments.

\section{ACKNOWLEDGEMENT}

We would like to thank the Editor, Professor Praveen Kumar, the Associate Editor, and the two anonymous referees for valuable comments and suggestions.

${ }^{1}$ As we used listed firms, market value of equity appears more relevant in the estimation of leverage. However, we checked the robustness of our results using book values as well. The results are similar and to conserve space and avoid repetition, we report the results using market values. 
${ }^{1}$ In identifying the controlling shareholder, we follow CSRC's definition of the "ultimate owner" of a publicly listed company as: (1) the largest shareholder, or (2) the shareholder with more voting power than the largest shareholder, or (3) the shareholder with shareholding or voting rights above $30 \%$ of the total shares, or voting rights in the company, or (4) the shareholder who can determine over half of the board members. This is consistent with the extensive prior literature such as Jiang et al. (2010); Liu and Tian (2012); and Liao et al. (2014).

${ }^{1}$ Data on the voting rights of the non-controlling multiple large shareholders are unavailable; hence, the control contestability ratios are calculated using collective shareholdings of the multiple large shareholders and the control rights of the controlling shareholder.

\section{REFERENCES}

Anderson, R. \& Reeb, D. 2004. Board composition: Balancing family influence in S\&P 500 firms, Administrative Science Quarterly, 49(2): 209-237.

Allen, F., Qian, J. \& Qian, M. 2005. Law, finance, and economic growth in China, Journal of Financial Economics 77: 57-116.

Arellano, M., \& Bover. O. 1995. Another look at the instrumental variable estimation of errorcomponents models, Journal of Econometrics, 68: 29-51.

Blundell, R \& Bond, S. 1998. Initial conditions and moment restrictions in dynamic panel data model, Journal of Econometrics, 87: 115-143.

Attig, N., Guedhami, O. \& Mishra, D. 2008. Multiple large shareholders, control contests and implied cost of equity, Journal of Corporate Finance, 14: 721-737.

Attig, N., El Ghoul, S. \& Guedhami, O. 2009. Do multiple large shareholders play a corporate governance role? Evidence from East Asia, Journal of Financial Research, 32 (4): 395-422.

Attig, N., El Ghoul, S. \& Guedhami, O. 2013. The governance role of multiple large shareholders: evidence from the valuation of cash holding, Journal of Management and Governance, 17:419-451.

Berger P.G, Ofek E \& Yermarck D. L. 1997. Managerial entrenchment and capital structure decisions, Journal of Finance, 52(4): 1411-1438. 
Berglof, E. \& Pajuste, A. 2003. Emerging owners, eclipsing market? Corporate governance in Central and Eastern Europe. In P.K. Cornelius \& B. Kogut (Eds.). Corporate governance and capital flows in a global economy, Oxford: Oxford University Press.

Bennedsen, M. \& Wolfenzon, D. 2000. The balance of power in closely held corporations, Journal of Financial Economics, 58:113-139.

Buchuk, D., Larrain, B., Muñoz, F., \& Urzúa, I. F. 2014. The internal capital markets of business groups: Evidence from intra-group loans, Journal of Financial Economics, 112, 190-212.

Casado, R. B, Burkert, M, Davila, A. \& Oyon, D. 2016. Shareholder Protection: The Role of Multiple Large Shareholders, Corporate Governance: An International Review, 24(2): 105-129.

Chang, Y-K, Chou, R.K. \& Huang, T-H. 2014. Corporate governance and the dynamics of capital structure: New evidence, Journal of Banking \& Finance, 48: 374-385.

Cheung, Y., Jing, L., Rau, R., \& Stoutaitis, A. 2006. Tunneling, propping, and expropriation: evidence from connected party transactions in Hong Kong, Journal of Financial Economics, 82: 343-386.

Claessens, S., Djankov, S., Fan, J. \& Lang, L. 2002. Disentangling the incentive and entrenchment of large shareholdings, Journal of Finance, 57 (6): 2741-2771.

Claessens, S., Djankov, S. \& Lang, L. 2000. The separation of ownership and control in East Asian corporations, Journal of Financial Economics, 58: 81-112.

Cull, R., Li, W., Sun, B., \& Xu, L. C. 2015. Government connections and financial constraints: Evidence from a large representative sample of Chinese firms, Journal of Corporate Finance, 32: 271-294.

Dharwadkar, R., George, G. \& Brandes, P. 2000. Privatization in emerging economies: an agency theory perspective, Academy of Management Review, 25, 650-69.

Djankov, S., La Porta, R., Lopez-de-Silanes, F., \& Shleifer, A. 2008. The law and economics of self-dealing. Journal of Financial Economics, 88: 430-465.

Faccio, M. 2010. Difference between politically connected and non-connected firms: A cross country analysis, Financial Management, 39 (3): 905-928.

Faccio, M., Lang, L.H.P. \& Young, L. 2010. Pyramiding vs. leverage in corporate groups: international evidence, Journal of International Business Studies, 41: 88-104.

Faccio, M \& Lang, L.H.P. 2002. The ultimate ownership of Western European corporations. Journal of Financial Economics, 65(3): 365-395. 
Faccio, M. Lang, L. \& Young, L. 2001. Dividends and expropriation, American Economic Review, 91: 54-78.

Fan, J P.H., Wei, K.C.J \& Xu, X. 2011. Corporate finance and governance in emerging markets: A selective review and an agenda for future research, Journal of Corporate Finance, 17(2):207214.

Firth, M., Lin, C., \& Zou, H. 2010. Friend or Foe? The Role of State and Mutual Fund Ownership in the Split Share Structure Reform in China. Journal of Financial and Quantitative Analysis, 45 (3): 685-706.

Friedman, E., Johnson, S. \& Milton, T. 2003. Propping and tunneling, Journal of Comparative Economics, 31, 732-750.

Gedajlovic, E. R., Lubatkin, M. H. \& Schulze, W. S. 2004. Crossing the threshold from founder management to professional management: A governance perspective, Journal of Management Studies, 41: 988-12.

Gomes, A. \& Novaes, W. 2005. Sharing of control versus monitoring as corporate governance mechanism, PIER Working Paper No. 01-029, University of Pennsylvania. Available at SSRN:http://ssrn.com/abstract=277111.

Guedhami, O. \& Mishra, D. 2009. Excess control, corporate governance, and implied cost of equity: International evidence, Financial Review, 44: 489-524.

Gutierrez, L.H. \& Pombo, C. 2009. Corporate ownership and control contestability in emerging markets: The case of Colombia, Journal of Economics and Business, 61: 112-139.

Jameson, M., Prevost, A. \& Puthenpurackai, J. 2015. Controlling shareholders, board structure, and firm performance: Evidence from India, Journal of Corporate Finance, 27: 1-20.

Jensen, M., \& Meckling, W. 1976. Theory of the firm: managerial behavior, agency costs, and ownership structure, Journal of Financial Economics, 3: 305-360.

Jiang, G, Lee, C.M.C \& Yue, H. 2010. Tunneling through intercorporate loans: The China experience. Journal of Financial Economics, 98: 1-20.

Jiang, Y. \& Peng, M.W. 2011. Principal-principal conflicts during crisis, Asia Pacific Journal of Management, 28(4): 683-695.

Jiang, G., Rao, P., \& Yue, H. 2015. Tunneling through Non-Operational Fund Occupancy: An investigation based on officially identified activities, Journal of Corporate Finance, 32: 295311 
Jiang, F \& Kim, K.A. 2015. Corporate governance in China: A modern perspective, Journal of Corporate Finance, 32:190-216.

Kahn, C. \& Winton, A. 1998. Ownership structure, speculation, and shareholder intervention. Journal of Finance, 53:99-129.

Kumar, P. and Zattoni, A. 2014. Large shareholders and corporate governance outside the United States and United Kingdom, Corporate Governance: An International Review, 22: 294-294

La Porta, R., Lopez-De-Silanes, F., \& Shleifer, A. 1999. Corporate ownership around the world. Journal of Finance, 54: 471-517.

La Porta, R., Lopez-de-Silanes, F., Shleifer, A. \& Vishny, R. 2002. Investor protection and corporate valuation, Journal of Finance, 57: 1147-70.

Laeven, L., \& Levine, R. 2008. Complex ownership structures and corporate valuations, Review of Financial Studies, 21: 579-604.

Lehman, E. \& Weigand, J. 2000. Does the governed corporation perform better? Governance structures and corporate performance in Germany. European Finance Review, 4: 157-195.

Li, K., Lu, L., Mittoo, U.R. \& Zhang, Z. 2015. Board independence, ownership concentration and corporate performance - Chinese evidence, International Review of Financial Analysis, 41: $162-175$.

Liao, L., Liu, B., \& Wang, H. 2014. China's secondary privatization: Perspectives from the SplitShare Structure Reform, Journal of Financial Economics, 113: 500-518.

Lins, K.V. 2003. Equity ownership and firm value in emerging markets, Journal of Financial and Quantitative Analysis, 38: 159-184.

Lin, C., Ma, Y., Malatesta, P., \& Xuan, Y. 2011. Ownership structure and the cost of corporate borrowing, Journal of Financial Economics, 100, 1-23.

Liu, Q. \& Tian G. (2012). Controlling shareholder, expropriations and firm's leverage decision: Evidence from Chinese non-tradable share reform, Journal of Corporate Finance, 18: 782-803.

Luo, J. H., Wan, D. F., \& Cai, D. 2012. The private benefits of control in Chinese listed firms: Do cash flow rights always reduce controlling shareholders' tunneling? Asia Pacific Journal of Management, 29(2): 449-518.

Mishra, D.R. 2011. Multiple large shareholders and corporate risk taking: Evidence from East Asia, Corporate Governance: An International Review, 19:507-528. 
Modigliani, F \& Miller, M. 1958. The cost of capital, corporation finance and the theory of investment, American Economic Review, 48: 261-297.

Morck, R., Wolfenzon, D. \& Yeung, B. 2005. Corporate governance, economic entrenchment, and growth, Journal of Economic Literature, 43(3): 655-720.

Maury, B. \& Pajuste, A. 2005. Multiple large shareholders and firm value, Journal of Banking and Finance, 29:1813-1834.

Morch, R., Shleifer, A \& Vishny, R. 1988. Management ownership and market valuation: An empirical analysis, Journal of Financial Economics, 20: 293-315.

Pagano, M. \& Roell, A. 1998. The choice of stock ownership structure, monitoring and the decision to go public, Quarterly Journal of Economics, 113:187-225

Paligorova, T. \& Xu, Z. 2012. Complex ownership and capital structure, Journal of Corporate Finance, 18: 701-716.

Peng, M.W. \& Jiang, Y. 2010. Institutions behind family ownership and control in large firms, Journal of Management Studies, 47(2): 253-273.

Peng, W.Q., Wei, K.C.L \& Yang, Z. 2010. Tunneling or propping: evidence from connected transaction in China, Journal of Corporate Finance, 17:306-325.

Poncet, S., Steingress, W., \& Vandenbussche, H. 2010. Financial constraints in China: firm-level evidence. China Economic Review, 21: 411-422.

Qian, M., \&Yeung, B. 2015. Bank financing and corporate governance, Journal of Corporate Finance, 32: 258-270.

Shevlin, T., Tang, T., \& Wilson, R. 2012. Domestic income shifting by Chinese listed firms, Journal of American Tax Association, 34: 1-29.

Shleifer, A. \& Vishny, R. 1997. A survey of corporate governance, Journal of Finance, 52: 737783.

Su, Y., Xu, D \& Plan, P.H. 2008. Principal-Principal Conflict in the Governance of the Chinese Public Corporation, Management and Organisation Review, 4 (1): 17-38.

Sun, Q., Tong, W.H.S. \& Tong, J. 2002. How does Ownership affect Firm Performance? Evidence from China's Privatisation Experience, Journal of Business Finance and Accounting, $29(1 / 2): 1-27$.

Sun, Q., \& Tong, W.H.S. 2003. China share issue privatization: the extent of its success, Journal of Financial Economics, 70: 183-222. 
Windmeijer, F. 2005. A finite sample correction for the variance of linear efficient two-step GMM estimators, Journal of Econometrics, 126: 25-51.

Wintoki M, Linck J. \& Netter J. 2012. Endogeneity and the dynamics of internal corporate governance, Journal of Financial Economics, 105(3): 581-606.

Wright, M., Filatotchev, I, Hoskinsson, R.E. \& Peng, M.W. 2005. Strategy research in emerging economies: challenging the conventional wisdom, Journal of Management Studies, 42: 1-33.

Young, M.N., Peng, M.W, Ahlstrom, D., Bruton, G.D \& Jiang, Y. 2008. Corporate governance in Emerging Economies: A Review of the Principal-Principal perspectives, Journal of Management Studies, 45: 197-220.

Zhang, M., Gao, S., Guan, X. \& Jiang, F. 2014. Controlling Shareholder-Manager Collusion and Tunneling: Evidence from China, Corporate Governance: An International Review, 22(6): 440459.

Zwiebel, J. 1995. Block investment and partial benefits of corporate control, Review of Economic Studies, 62: 161-185.

Agyenim Boateng is Professor of Finance \& Banking at the Glasgow Caledonian University, UK. He earned his PhD from the University of Leeds, UK. His research interests are in the area of corporate finance, firm governance and bank risk-taking. He has published over 40 articles in a number of international journals including: International Journal of Accounting, International Review of Financial Analysis, Review of Quantitative Finance \& Accounting, Journal of International Financial Markets, Institutions \& Money and International Business Review. His research has won a number of awards including: Emerald Citations of Excellence Award, 2015; and 2013 Elsevier Best Paper Award.

Wei Huang is an Assistant Professor of Finance in The University of Nottingham's China campus located in Ningbo. He has a $\mathrm{PhD}$ in Finance from the University of Bristol, and a Financial Risk Manager designation. Wei's research interest lies in the areas of corporate finance and corporate governance in China. He has supervised a number of $\mathrm{PhD}$ students to completion in these areas and published over a dozen articles in high quality finance journals such as Journal of International Financial Markets, Institutions \& Money, Review of Quantitative Finance and Accounting, International Review of Financial Analysis, Small Business Economics, and Applied Economics. 
Table 1: Summary Statistics

\begin{tabular}{|c|c|c|c|c|c|}
\hline Variable & Obs. & Mean & $\begin{array}{l}\text { Std. } \\
\text { Dev. }\end{array}$ & Min & Max \\
\hline Leverage & 15790 & 28.82 & 20.54 & 1.17 & 80.60 \\
\hline EX_Leverage & 15790 & 1.23 & 19.17 & -33.39 & 51.40 \\
\hline INC_LOAN & 15765 & 2.56 & 4.56 & 0.02 & 32.58 \\
\hline CF_Rights1 & 15790 & 37.27 & 15.41 & 9.09 & 75.00 \\
\hline CN_Rights 1 & 14845 & 39.68 & 15.60 & 10.00 & 75.43 \\
\hline CF_Rights2 & 15790 & 12.93 & 10.02 & 0.33 & 39.71 \\
\hline CF_Rights9 & 15790 & 20.67 & 13.45 & 0.93 & 54.44 \\
\hline $\mathrm{CF}_{-}^{-}$Contest2 & 15790 & 0.45 & 0.41 & 0.01 & 1.69 \\
\hline $\mathrm{CF}_{-}^{-}$Contest 9 & 15790 & 0.74 & 0.66 & 0.02 & 3.16 \\
\hline CN_Contest2 & 14845 & 0.40 & 0.35 & 0.01 & 1.58 \\
\hline CN_Contest9 & 14845 & 0.65 & 0.54 & 0.02 & 2.75 \\
\hline EX_PAY & 15790 & 0.10 & 0.70 & -3.55 & 3.28 \\
\hline $\mathrm{GOV}$ & 15790 & 0.50 & 0.50 & 0.00 & 1.00 \\
\hline NT_shares & 15790 & 36.54 & 27.78 & 0.00 & 83.17 \\
\hline CEŌ_Duality & 15790 & 0.80 & 0.40 & 0.00 & 1.00 \\
\hline Markèt CAP & 15790 & 21.88 & 1.08 & 19.21 & 24.96 \\
\hline $\mathrm{ROA}$ & 15790 & 6.24 & 7.22 & -23.51 & 29.46 \\
\hline TAX & 15790 & 20.21 & 7.36 & 0.00 & 33.00 \\
\hline CF/Sales & 15790 & 7.48 & 23.57 & -110.44 & 86.61 \\
\hline Board_IND & 15790 & 36.09 & 6.00 & 0.00 & 55.56 \\
\hline Investment & 15790 & 6.44 & 7.82 & -7.53 & 41.35 \\
\hline \multicolumn{6}{|c|}{ 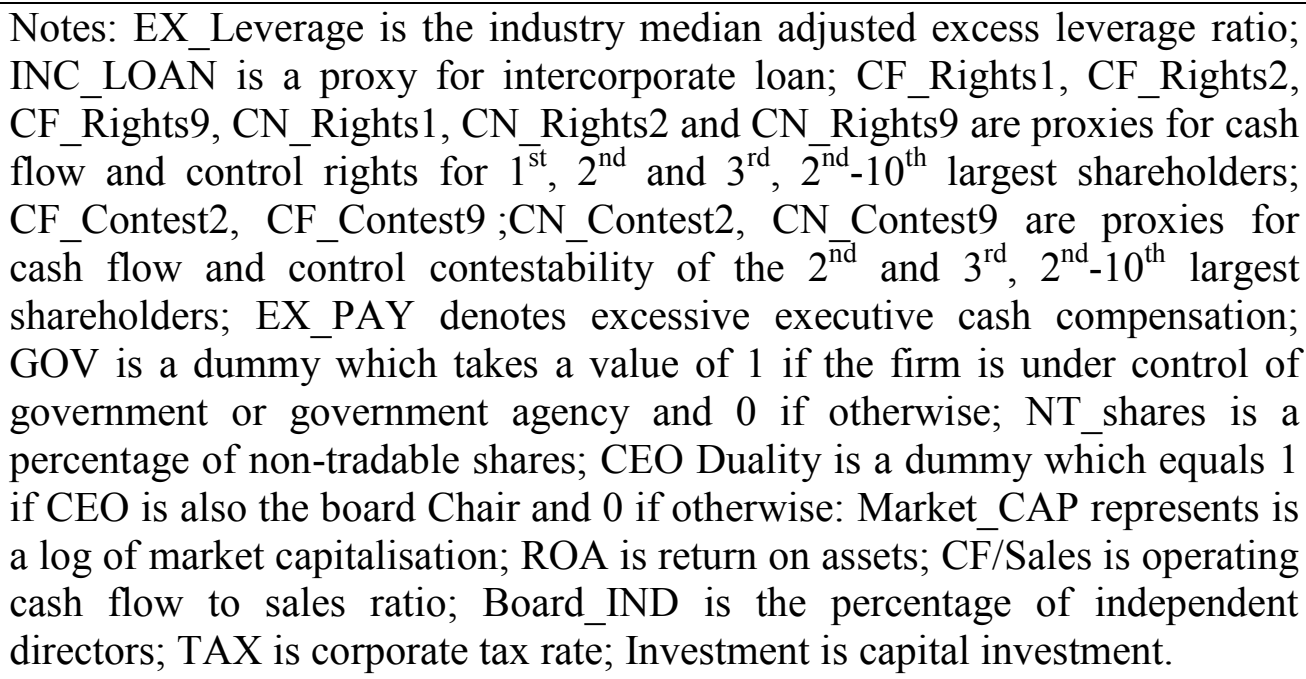 } \\
\hline
\end{tabular}


Table 2: Correlations Matrix

\begin{tabular}{|c|c|c|c|c|c|c|c|c|c|c|c|c|c|c|c|}
\hline & 1 & 2 & 3 & 4 & 5 & 6 & 7 & 8 & 9 & 10 & 11 & 12 & 13 & 14 & 15 \\
\hline 1. EX_Leverage & $0.93 * *$ & & & & & & & & & & & & & & \\
\hline 2. INC_LOAN & $0.16 * *$ & $0.12 * *$ & & & & & & & & & & & & & \\
\hline 3. $\mathrm{CF} \_\bar{C}$ Contest 2 & $-0.15 * *$ & $-0.12 * *$ & $0.02 * *$ & & & & & & & & & & & & \\
\hline 4. CF_Contest9 & $-0.19 * *$ & $-0.16 * *$ & $0.01 * *$ & $0.92 * *$ & & & & & & & & & & & \\
\hline 5. CN_Contest 2 & $-0.11 * *$ & $-0.08 * *$ & $0.07 * *$ & $0.89 * *$ & $0.79 * *$ & & & & & & & & & & \\
\hline 6. CN_Contest9 & $-0.15 * *$ & $-0.13 * *$ & $0.06 * *$ & $0.81 * *$ & $0.87 * *$ & $0.91 * *$ & & & & & & & & & \\
\hline 7. EX PAY & $0.12 * *$ & $0.12 * *$ & $-0.10 * *$ & $0.07 * *$ & $0.07 * *$ & $0.06 * *$ & $0.06 * *$ & & & & & & & & \\
\hline 8. $\mathrm{GOV}$ & $0.28 * *$ & $0.24 * *$ & $-0.03 * *$ & $-0.25 * *$ & $-0.28 * *$ & $-0.21 * *$ & $-0.25 * *$ & $0.04 * *$ & & & & & & & \\
\hline 9. NT_Share & $-0.17 * *$ & $-0.14 * *$ & $0.02 * *$ & $0.17 * *$ & $0.14 * *$ & $0.13 * *$ & $0.11 * *$ & $-0.13 * *$ & $-0.20 * *$ & & & & & & \\
\hline 10. CEO Duality & $0.17 * *$ & $0.15 * *$ & $0.03 * *$ & $-0.09 * *$ & $-0.09 * *$ & $-0.08 * *$ & $-0.09 * *$ & $-0.06 * *$ & $0.27 * *$ & $-0.12 * *$ & & & & & \\
\hline 11. Market_CAP & $-0.12 * *$ & $-0.13 * *$ & $-0.25 * *$ & $-0.10 * *$ & $-0.08 * *$ & $-0.13 * *$ & $-0.11 * *$ & $-0.11 * *$ & $0.20 * *$ & $-0.15 * *$ & $0.07 * *$ & & & & \\
\hline 12. ROA & $-0.31 * *$ & $-0.29 * *$ & $-0.21 * *$ & $0.04 * *$ & $0.07 * *$ & $0.02 * *$ & $0.05 * *$ & $-0.04 * *$ & $-0.06 * *$ & $0.14 * *$ & $-0.02 * *$ & $0.34 * *$ & & & \\
\hline 13. TAX & $0.22 * *$ & $0.13 * *$ & $0.12 * *$ & $-0.09 * *$ & $-0.11 * *$ & $-0.04 * *$ & $-0.07 * *$ & $-0.13 * *$ & $0.12 * *$ & $-0.02 * *$ & $0.11 * *$ & $-0.07 * *$ & $-0.04 * *$ & & \\
\hline 14. CF_Sales & $-0.08 * *$ & $-0.05 * *$ & -0.08 & 0.00 & 0.00 & 0.01 & $0.00 * *$ & $-0.04 * *$ & $0.07 * *$ & $0.03 * *$ & $0.02 * *$ & $0.10 * *$ & $0.19 * *$ & 0.00 & \\
\hline 15. Board_IND & $-0.02 * *$ & $-0.03 * *$ & -0.03 & 0.00 & $0.02 * *$ & -0.02 & $-0.01 * *$ & $0.01 * *$ & $-0.08 * *$ & $-0.03 * *$ & $-0.09 * *$ & $0.09 * *$ & $-0.01 * *$ & $-0.03 * *$ & -0.04 \\
\hline
\end{tabular}

Notes: EX_Leverage is industry median adjusted excess leverage ratio; INC_LOAN is a proxy for intercorporate loans; CF_Contest2, CF_Contest9, CN_Contest 2 and CN_Contest9 are proxies of the cash flow and control contestability for $2^{\text {nd }}$ and $3^{\text {rd }}, 2^{\text {nd }}-10^{\text {th }} 1$ largest shareholders; EX PAY denotes excessive executive cash compensation; GOV is a dummy which takes a value of 1 if the firm is under control of government or government agency and 0 if otherwise; NT_Share is a percentage of non-tradable shares; CEO Duality is a dummy which equals 1 if CEO is also the board Chair and 0 if otherwise: Market_CAP represents market capitalisation; ROA is return on assets; CF/Sales is operating cash flow to sales ratio; Board_IND is the percentage of directors who are independent; TAX is corporate tax rate.

$* * \mathrm{p}<.05$ 
Table 3: Baseline Regression Results: Ownership, Control, and Excess Leverage

\begin{tabular}{|c|c|c|c|c|}
\hline \multirow[b]{2}{*}{ Variables } & \multicolumn{2}{|c|}{ Excess Leverage } & \multirow[b]{2}{*}{ Model 3} & \multirow[b]{2}{*}{ Model 4} \\
\hline & Model 1 & Model 2 & & \\
\hline CF_Rights2 & $\begin{array}{c}-0.156^{* *} \\
(-2.44)\end{array}$ & & $\begin{array}{c}-0.211 * * * \\
(-2.99)\end{array}$ & \\
\hline CF_Rights9 & & $\begin{array}{c}-0.105^{* *} \\
(-2.32)\end{array}$ & & $\begin{array}{c}-0.144 * * * \\
(-2.84)\end{array}$ \\
\hline EX_PAY & $\begin{array}{c}16.434 * * * \\
(26.72)\end{array}$ & $\begin{array}{c}16.568 * * * \\
(26.81)\end{array}$ & $\begin{array}{c}16.165 * * * \\
(25.30)\end{array}$ & $\begin{array}{c}16.345 * * * \\
(25.26)\end{array}$ \\
\hline GOV & $\begin{array}{c}29.991 * * * \\
(12.90)\end{array}$ & $\begin{array}{c}29.676^{* * * *} \\
(13.07)\end{array}$ & $\begin{array}{c}32.091 * * * \\
(13.29)\end{array}$ & $\begin{array}{c}32.111 * * * \\
(13.41)\end{array}$ \\
\hline CEO Duality & $\begin{array}{c}3.486^{* * * *} \\
(6.42)\end{array}$ & $\begin{array}{c}3.683^{* * * *} \\
(6.77)\end{array}$ & $\begin{array}{c}3.698 * * * \\
(6.69)\end{array}$ & $\begin{array}{c}3.761 * * * \\
(6.81)\end{array}$ \\
\hline Market_CAP & $\begin{array}{c}-9.274 * * * \\
(-28.58)\end{array}$ & $\begin{array}{c}-9.165 * * * \\
(-29.13)\end{array}$ & $\begin{array}{c}-9.435^{* * * *} \\
(-28.06)\end{array}$ & $\begin{array}{c}-9.294 * * * \\
(-28.41)\end{array}$ \\
\hline CF_Sales & $\begin{array}{c}-0.027 * * * \\
(-4.83)\end{array}$ & $\begin{array}{c}-0.027 * * * \\
(-4.82)\end{array}$ & $\begin{array}{c}-0.024 * * * \\
(-4.08)\end{array}$ & $\begin{array}{c}-0.024 * * * \\
(-4.05)\end{array}$ \\
\hline Board_IND & $\begin{array}{c}0.104^{* * *} \\
(3.14)\end{array}$ & $\begin{array}{c}0.101 * * * \\
(3.07)\end{array}$ & $\begin{array}{c}0.136^{* * *} \\
(3.70)\end{array}$ & $\begin{array}{c}0.134 * * * \\
(3.65)\end{array}$ \\
\hline L.EX_Leverage & $\begin{array}{c}0.315^{* * * *} \\
(22.65)\end{array}$ & $\begin{array}{c}0.312^{* * * *} \\
(22.55)\end{array}$ & $\begin{array}{c}0.308^{* * *} * \\
(20.71)\end{array}$ & $\begin{array}{c}0.305^{* * *} \\
(20.56)\end{array}$ \\
\hline Observations. & 14,500 & 14,500 & 13,699 & 13,699 \\
\hline Number of Firms & 2,341 & 2,341 & 2,330 & 2,330 \\
\hline
\end{tabular}




\begin{tabular}{lllll} 
AR(2) & 0.13 & 0.14 & 0.06 & 0.07 \\
Sargan & 0.32 & 0.37 & 0.33 & 0.32 \\
\hline
\end{tabular}

Notes: We use the two-step dynamic panel-data system estimator with bias-corrected robust standard errors in all models; $t$-statistics in parentheses.

The dependent variable (Ex Leverage) is industry median adjusted excess leverage ratio; INC LOAN is a proxy for intercorporate loan; CF Rights $1, C F$ Rights 2 and CF Rights9 are proxies of the cash flow rights for $1^{\text {st }}, 2^{\text {nd }}$ and $3^{\text {rd }}, 2^{-1 \text { nd }}-10^{\text {th }}$ largest shareholders; CN_Rights 1 is a proxy for control rights of the controlling shareholders; EX_PAY is excessive executive cash compensation; GOV is a dummy for government or government agency of the firm; NT share is a percentage of non-tradable shares; CEO Duality is a dummy if CEO is also the board Chair: Market_CAP represents is a log of market capitalisation; TAX is a corporate tax rate; ROA is return on assets; CF/Sales is operating cash flow to sales ratIo; Board_IND is the percentage of independent directors; Investment is .capital investment.

$* * * \mathrm{P}<.01$

$* * \mathrm{P}<.05$ 
Table 4: Multiple Large Shareholders and Excess Leverage

\begin{tabular}{|c|c|c|c|c|c|c|c|c|}
\hline \multirow[t]{2}{*}{ Dependent Var } & \multicolumn{8}{|c|}{ Excess $\quad$ Leverage } \\
\hline & Model 1 & Model 2 & Model 3 & Model 4 & Model 5 & Model 6 & Model 7 & Model 8 \\
\hline CF_Contest 2 & $\begin{array}{c}-4.929 * * \\
(-2.46)\end{array}$ & & & & $\begin{array}{c}-11.067 * * * \\
(-4.80)\end{array}$ & & & \\
\hline CF_Contest 9 & & $\begin{array}{c}-3.070 * * \\
(-2.26)\end{array}$ & & & & $\begin{array}{c}-8.113 * * * \\
(-5.22)\end{array}$ & & \\
\hline CN_Contest2 & & & $\begin{array}{c}-10.282 * * * \\
(-4.33)\end{array}$ & & & & $\begin{array}{c}-14.266 * * * \\
(-5.58)\end{array}$ & \\
\hline CN_Contest9 & & & & $\begin{array}{c}-7.186^{* * *} \\
(-4.41)\end{array}$ & & & & $\begin{array}{c}-10.319^{* * *} \\
(-5.85)\end{array}$ \\
\hline CF_Contest $2 * \mathrm{GOV}$ & & & & & $\begin{array}{c}14.358^{* * * *} \\
(4.31)\end{array}$ & & & \\
\hline CF_Contest $9 * \mathrm{GOV}$ & & & & & & $\begin{array}{c}10.172 * * * \\
\quad(4.22)\end{array}$ & & \\
\hline CN_Contest $2 * G O V$ & & & & & & & $\begin{array}{c}9.394 * * * \\
(2.79)\end{array}$ & \\
\hline CN_Contest $9 * \mathrm{GOV}$ & & & & & & & & $\begin{array}{c}8.006^{* * *} \\
(3.22)\end{array}$ \\
\hline EX_PAY & $\begin{array}{c}14.816^{* * *} \\
(18.49)\end{array}$ & $\begin{array}{c}15.030^{* * *} \\
(18.59)\end{array}$ & $\begin{array}{c}14.478^{* * *} \\
(16.96)\end{array}$ & $\begin{array}{c}14.609^{* * *} \\
(17.04)\end{array}$ & $\begin{array}{c}13.682 * * * \\
(18.44)\end{array}$ & $\begin{array}{c}13.939 * * * \\
(18.64)\end{array}$ & $\begin{array}{c}13.019 \text { *** } \\
(17.01)\end{array}$ & $\begin{array}{c}13.322 * * * \\
(17.05)\end{array}$ \\
\hline GOV & $\begin{array}{c}37.170^{* * * *} \\
(12.86)\end{array}$ & $\begin{array}{c}38.759 * * * \\
(12.88)\end{array}$ & $\begin{array}{c}37.410^{* * *} \\
(12.97)\end{array}$ & $\begin{array}{c}38.419 * * * \\
(12.80)\end{array}$ & $\begin{array}{c}18.209^{* * *} \\
(7.51)\end{array}$ & $\begin{array}{c}19.788^{* * *} \\
(6.90)\end{array}$ & $\begin{array}{c}19.641 * * * \\
(8.66)\end{array}$ & $\begin{array}{c}21.166^{* * * *} \\
(8.21)\end{array}$ \\
\hline NT_Share & $\begin{array}{c}-0.032 * * * \\
(-3.19)\end{array}$ & $\begin{array}{c}-0.031 * * * \\
(-2.93)\end{array}$ & $\begin{array}{c}-0.019^{*} \\
(-1.86)\end{array}$ & $\begin{array}{l}-0.016 \\
(-1.57)\end{array}$ & $\begin{array}{c}-0.043 * * * \\
(-4.52)\end{array}$ & $\begin{array}{c}-0.039 * * * \\
(-3.93)\end{array}$ & $\begin{array}{c}-0.037 * * * \\
(-3.78)\end{array}$ & $\begin{array}{c}-0.032 * * * \\
(-3.25)\end{array}$ \\
\hline CEO Duality & $\begin{array}{c}2.635^{* * * *} \\
(4.98)\end{array}$ & $\begin{array}{c}2.380 * * * \\
(4.58)\end{array}$ & $\begin{array}{c}2.749 * * * \\
(5.18)\end{array}$ & $\begin{array}{c}2.527 * * * \\
(4.83)\end{array}$ & $\begin{array}{c}3.427 * * * \\
(6.33)\end{array}$ & $\begin{array}{c}3.177 * * * \\
(5.99)\end{array}$ & $\begin{array}{c}3.640 * * * \\
(6.74)\end{array}$ & $\begin{array}{c}3.298^{* * *} \\
(6.19)\end{array}$ \\
\hline Market_CAP & $\begin{array}{c}-10.393 * * * \\
(-25.52)\end{array}$ & $\begin{array}{c}-10.250 * * * \\
(-25.24)\end{array}$ & $\begin{array}{c}-10.605^{* * *} \\
(-24.44)\end{array}$ & $\begin{array}{c}-10.356^{* * *} \\
(-24.33)\end{array}$ & $\begin{array}{c}-10.600 * * * \\
(-27.78)\end{array}$ & $\begin{array}{c}-10.496 * * * \\
(-27.49)\end{array}$ & $\begin{array}{c}-10.899 * * * \\
(-27.60)\end{array}$ & $\begin{array}{c}-10.644 * * * \\
(-27.02)\end{array}$ \\
\hline
\end{tabular}




\begin{tabular}{|c|c|c|c|c|c|c|c|c|}
\hline TAX & $\begin{array}{c}-0.108 * * * \\
(-3.53)\end{array}$ & $\begin{array}{c}-0.109 * * * \\
(-3.59)\end{array}$ & $\begin{array}{c}-0.118^{* * *} \\
(-3.71)\end{array}$ & $\begin{array}{c}-0.109^{* * *} \\
(-3.42)\end{array}$ & $\begin{array}{c}-0.072 * * \\
(-2.49)\end{array}$ & $\begin{array}{c}-0.086 * * * \\
(-2.96)\end{array}$ & $\begin{array}{c}-0.069 * * \\
(-2.30)\end{array}$ & $\begin{array}{c}-0.073 * * \\
(-2.45)\end{array}$ \\
\hline ROA & $\begin{array}{l}-0.035 \\
(-1.36)\end{array}$ & $\begin{array}{l}-0.031 \\
(-1.20)\end{array}$ & $\begin{array}{l}-0.015 \\
(-0.52)\end{array}$ & $\begin{array}{l}-0.009 \\
(-0.34)\end{array}$ & $\begin{array}{c}-0.051 * * \\
(-2.03)\end{array}$ & $\begin{array}{c}-0.050 * * \\
(-1.98)\end{array}$ & $\begin{array}{l}-0.036 \\
(-1.29)\end{array}$ & $\begin{array}{l}-0.034 \\
(-1.26)\end{array}$ \\
\hline CF/Sales & $\begin{array}{c}-0.030 * * * \\
(-5.34)\end{array}$ & $\begin{array}{c}-0.030 * * * \\
(-5.30)\end{array}$ & $\begin{array}{c}-0.028^{* * *} \\
(-4.87)\end{array}$ & $\begin{array}{c}-0.027 * * * \\
(-4.70)\end{array}$ & $\begin{array}{c}-0.033 * * * \\
(-5.78)\end{array}$ & $\begin{array}{c}-0.032 * * * \\
(-5.49)\end{array}$ & $\begin{array}{c}-0.032 * * * \\
(-5.53)\end{array}$ & $\begin{array}{c}-0.030 * * * \\
(-5.24)\end{array}$ \\
\hline Board_IND & $\begin{array}{c}0.085 * * * \\
(2.58)\end{array}$ & $\begin{array}{c}0.096^{* * *} * \\
(2.90)\end{array}$ & $\begin{array}{c}0.123 * * * \\
(3.43)\end{array}$ & $\begin{array}{c}0.130 * * * \\
(3.65)\end{array}$ & $\begin{array}{c}0.081^{* *} \\
(2.42)\end{array}$ & $\begin{array}{c}0.107 * * * \\
(3.19)\end{array}$ & $\begin{array}{c}0.104 * * * \\
(2.90)\end{array}$ & $\begin{array}{c}0.127 * * * \\
(3.54)\end{array}$ \\
\hline L.EX_Leverage & $\begin{array}{c}0.303 * * * \\
(20.45)\end{array}$ & $\begin{array}{c}0.298 * * * \\
(20.03)\end{array}$ & $\begin{array}{c}0.301 * * * \\
(19.41)\end{array}$ & $\begin{array}{c}0.293 * * * \\
(18.86)\end{array}$ & $\begin{array}{c}0.327 * * * \\
(23.57)\end{array}$ & $\begin{array}{c}0.320 * * * \\
(22.64)\end{array}$ & $\begin{array}{c}0.329 * * * \\
(22.73)\end{array}$ & $\begin{array}{c}0.317^{* * * *} \\
(21.72)\end{array}$ \\
\hline Constant & $\begin{array}{c}208.491 * * * \\
(21.29) \\
\end{array}$ & $\begin{array}{c}204.327^{* * *} \\
(21.04) \\
\end{array}$ & $\begin{array}{c}213.379 * * * \\
(20.30) \\
\end{array}$ & $\begin{array}{c}207.622 * * * \\
(20.16) \\
\end{array}$ & $\begin{array}{c}222.457 * * * \\
(24.60)\end{array}$ & $\begin{array}{c}219.358^{* * * *} \\
(24.21) \\
\end{array}$ & $\begin{array}{c}228.843 * * * \\
(24.29) \\
\end{array}$ & $\begin{array}{c}222.265^{* * *} * \\
(23.60)\end{array}$ \\
\hline Observations. & 14,500 & 14,500 & 13,699 & 13,699 & 14,500 & 14,500 & 13,699 & 13,699 \\
\hline Number of Firms & 2,341 & 2,341 & 2,330 & 2,330 & 2,341 & 2,341 & 2,330 & 2,330 \\
\hline $\mathrm{AR}(2)$ & 0.29 & 0.31 & 0.13 & 0.16 & 0.21 & 0.22 & 0.07 & 0.09 \\
\hline Sargan & 0.33 & 0.29 & 0.37 & 0.35 & 0.28 & 0.22 & 0.24 & 0.29 \\
\hline
\end{tabular}

Notes: We use the two-step dynamic panel-data system estimator with bias-corrected robust standard errors in all models. t-statistics in parentheses. The dependent variable (EX_Leverage) is the industry median adjusted excess financial leverage ratio; INC_LOAN is a proxy for intercorporate loans; CF_Contest2, CF_Contest9, CN_Contest 2 and CN_Contest 9 are proxies for cash flow and control contestability of the $2^{\text {nd }}$ and $3^{\text {rd }}, 2^{\text {nd }}-10^{\text {th }} 1$ largest shareholders; EX_PAY is excessive executive cash compensation; GOV is a dummy which takes a value of 1 if the firm is under control of government or government agency and 0 if otherwise; NT_share is a percentage of non-tradable shares; CEO Duality is a dummy which equals 1 if CEO is also the board Chair and 0 if otherwise: Market_CAP represents is a log of market capitalisation; TAX is corporate tax rate; ROA is return on assets; CF/Sales is operating cash flow to sales ratio; Board_IND is the percentage of independent directors; L.EX_Leverage is lagged excess leverage.

$* * * \mathrm{P}<.01$
$* * \mathrm{P}<05$ 
Table 5: Multiple Large Shareholders and Excess Leverage: Sub-sample Analysis

Panel A: Government versus Private Control: The Role of Multiple Large Shareholders

\begin{tabular}{|c|c|c|c|c|c|c|c|c|}
\hline & \multicolumn{3}{|c|}{ SOEs } & \multirow[b]{2}{*}{ Model 4} & \multicolumn{3}{|c|}{ POEs } & \multirow[b]{2}{*}{ Model 8} \\
\hline & Model 1 & Model 2 & Model 3 & & Model 5 & Model 6 & Model 7 & \\
\hline CF_Contest 2 & $\begin{array}{l}0.509 \\
(0.20)\end{array}$ & & & & $\begin{array}{c}-11.257 * * * \\
(-5.69)\end{array}$ & & & \\
\hline CF_Contest 9 & & & $\begin{array}{l}0.531 \\
(0.30)\end{array}$ & & & & $\begin{array}{c}-8.470 * * * \\
(-6.51)\end{array}$ & \\
\hline L.EX_Leverage & $\begin{array}{c}0.332 * * * \\
(18.69)\end{array}$ & $\begin{array}{c}0.338^{* * *} \\
(17.93)\end{array}$ & $\begin{array}{c}0.333 * * * \\
(18.87)\end{array}$ & $\begin{array}{c}0.334 * * * \\
(18.01)\end{array}$ & $\begin{array}{c}0.393 * * * \\
(21.09)\end{array}$ & $\begin{array}{c}0.386 * * * \\
(20.16)\end{array}$ & $\begin{array}{c}0.389 * * * \\
(20.60)\end{array}$ & $\begin{array}{c}0.380 * * * \\
(19.79)\end{array}$ \\
\hline Controls & YES & YES & YES & YES & YES & YES & YES & YES \\
\hline Observations & 7,634 & 7,058 & 7,634 & 7,058 & 6,866 & 6,641 & 6,866 & 6,641 \\
\hline No. of Firms & 961 & 952 & 961 & 952 & 1,382 & 1,380 & 1,382 & 1,380 \\
\hline AR(2) & 0.13 & 0.13 & 0.11 & 0.13 & 0.82 & 0.85 & 0.93 & 0.82 \\
\hline
\end{tabular}


Panel B: High Leverage versus Low Leverage: The Role of Multiple Large Shareholders

\begin{tabular}{|c|c|c|c|c|c|c|c|c|}
\hline & \multicolumn{4}{|c|}{ High Leverage } & \multicolumn{4}{|c|}{ Low Leverage } \\
\hline CF_Contest2 & $\begin{array}{l}-4.526 \\
(-1.55)\end{array}$ & & & & $\begin{array}{c}-3.993 * * \\
(-2.45)\end{array}$ & & & \\
\hline CN_Contest 2 & & $\begin{array}{c}-10.861 * * * \\
(-3.01)\end{array}$ & & & & $\begin{array}{c}-5.335 * * * \\
(-2.61)\end{array}$ & & \\
\hline CF_Contest 9 & & & $\begin{array}{c}-3.145^{*} \\
(-1.68)\end{array}$ & & & & $\begin{array}{c}-2.542 * * \\
(-2.55)\end{array}$ & \\
\hline L.EX_Leverage & $\begin{array}{c}0.194 * * * \\
(11.54)\end{array}$ & $\begin{array}{c}0.198 * * * \\
(11.20)\end{array}$ & $\begin{array}{c}0.194 * * * \\
(11.74)\end{array}$ & $\begin{array}{c}0.195^{* * *} \\
(11.11)\end{array}$ & $\begin{array}{c}0.304 * * * \\
(19.79)\end{array}$ & $\begin{array}{c}0.299 * * * \\
(19.14)\end{array}$ & $\begin{array}{c}0.304 * * * \\
(19.86)\end{array}$ & $\begin{array}{c}0.298 * * * \\
(19.15)\end{array}$ \\
\hline Controls & YES & YES & YES & YES & YES & YES & YES & YES \\
\hline Observations & 6,976 & 6,514 & 6,976 & 6,514 & 7,516 & 7,180 & 7,516 & 7,180 \\
\hline Number of Firms & 1,483 & 1,460 & 1,483 & 1,460 & 2,012 & 1,986 & 2,012 & 1,986 \\
\hline
\end{tabular}


Table 6: Controlling Shareholder Excess Control Rights, Multiple Large Shareholders, and Excess Leverage

\begin{tabular}{|c|c|c|c|}
\hline Variables & Model 1 & Model 2 & Model 3 \\
\hline DEXCON & $\begin{array}{c}3.323 * * * \\
(2.80)\end{array}$ & $\begin{array}{c}11.606^{* * *} \\
(4.16)\end{array}$ & $\begin{array}{c}8.455 * * * \\
(3.08)\end{array}$ \\
\hline CN_Contest 2 & & $\begin{array}{c}-5.526 * * \\
(-2.50)\end{array}$ & \\
\hline CN_Contest9 & & & $\begin{array}{c}-4.533 * * * \\
(-3.03)\end{array}$ \\
\hline DEXCON*CN_Contest2 & & $\begin{array}{c}-12.365 * * \\
(-2.51)\end{array}$ & \\
\hline DEXCON*CN_Contest9 & & & $\begin{array}{l}-3.727 \\
(-1.22)\end{array}$ \\
\hline EXPAY & $\begin{array}{c}14.936^{* * * *} \\
(18.82)\end{array}$ & $\begin{array}{c}13.633 * * * \\
(16.01)\end{array}$ & $\begin{array}{c}13.765 * * * \\
(16.33)\end{array}$ \\
\hline GOV_D & $\begin{array}{c}43.666^{* * * *} \\
(13.39)\end{array}$ & $\begin{array}{c}40.167 * * * \\
(13.54)\end{array}$ & $\begin{array}{c}40.378 * * * \\
(13.39)\end{array}$ \\
\hline NT_Shares & $\begin{array}{c}-0.040 * * * \\
(-4.31)\end{array}$ & $\begin{array}{c}-0.034 * * * \\
(-3.36)\end{array}$ & $\begin{array}{c}-0.031 * * * \\
(-2.99)\end{array}$ \\
\hline CEO Duality & $\begin{array}{c}2.246 * * * \\
(4.04)\end{array}$ & $\begin{array}{c}2.494 * * * \\
(4.27)\end{array}$ & $\begin{array}{c}2.366^{* * * *} \\
(4.14)\end{array}$ \\
\hline Market_CAP & $\begin{array}{c}-10.370 * * * \\
(-25.87)\end{array}$ & $\begin{array}{c}-10.861 * * * \\
(-25.83)\end{array}$ & $\begin{array}{c}-10.626 * * * \\
(-25.46)\end{array}$ \\
\hline TAX & $\begin{array}{c}-0.119 * * * \\
(-3.86)\end{array}$ & $\begin{array}{c}-0.115 * * * \\
(-3.56)\end{array}$ & $\begin{array}{c}-0.108 * * * \\
(-3.39)\end{array}$ \\
\hline $\mathrm{ROA}$ & $\begin{array}{l}-0.036 \\
(-1.38)\end{array}$ & $\begin{array}{l}-0.029 \\
(-1.03)\end{array}$ & $\begin{array}{l}-0.024 \\
(-0.87)\end{array}$ \\
\hline CF/Sales & $\begin{array}{c}-0.031 * * * \\
(-5.27)\end{array}$ & $\begin{array}{c}-0.029 * * * \\
(-4.79)\end{array}$ & $\begin{array}{c}-0.028 * * * \\
(-4.80)\end{array}$ \\
\hline Board_IND & $0.135 * * *$ & $0.109 * * *$ & $0.113 * * *$ \\
\hline
\end{tabular}




\begin{tabular}{lccc} 
& $(3.96)$ & $(2.90)$ & $(3.05)$ \\
L.EX_Leverage & $0.288^{* * *}$ & $0.291^{* * *}$ & $0.287^{* * *}$ \\
& $(18.91)$ & $(18.59)$ & $(18.55)$ \\
Constant & $200.501^{* * *}$ & $215.505^{* * *}$ & $210.810^{* * *}$ \\
& $(21.14)$ & $(21.67)$ & $(21.60)$ \\
\hline Observations. & 14,500 & 13,699 & 13,699 \\
Number of firms & 2,341 & 2,330 & 2,330 \\
AR(2) & 0.4 & 0.26 & 0.25 \\
Sargan & 0.22 & 0.27 & 0.19 \\
\hline
\end{tabular}

The dependent variable (EX_Leverage) is the industry median adjusted excess financial leverage ratio. We use the two-step dynamic panel-data system estimator with bias-corrected robust standard errors in all models. t-statistics in parentheses. All independent variables are considered as endogenous variables. We control for the first lag of the dependent variables in all models. We conduct the second order serial correlations test AR(2) and Sargan test of overidentifying restrictions. INC_LOAN is a proxy for intercorporate loans; CF_Contest2, CF_Contest9, CN_Contest 2 and CN_Contest9 are proxies for cash flow and control contestability of the $2^{\text {nd }}$ and $3^{\text {rd }}, 2^{\text {nd }}-10^{\text {th }}$ largest shareholders; DEXCON is a dummy which takes a value of 1 if the controlling shareholder's control rights is larger than the cash flow right; EX PAY denotes excessive executive cash compensation; GOV is a dummy for firms under control of government or government agency; NT_share is a percentage of non-tradable shares; CEO Duality is a dummy if CEO is also the board Chair: Market_CAP represents is a $\log$ of market capitalisation; TAX is corporate tax rate; ROA is return on assets; $\mathrm{CF} / \mathrm{Sales}$ is operating cash flow to sales ratio; Board_IND is the percentage of independent directors;

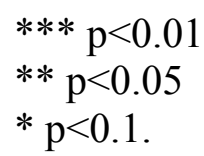


Table 7: Controlling shareholder excess control rights, multiple large shareholders, and Tunneling

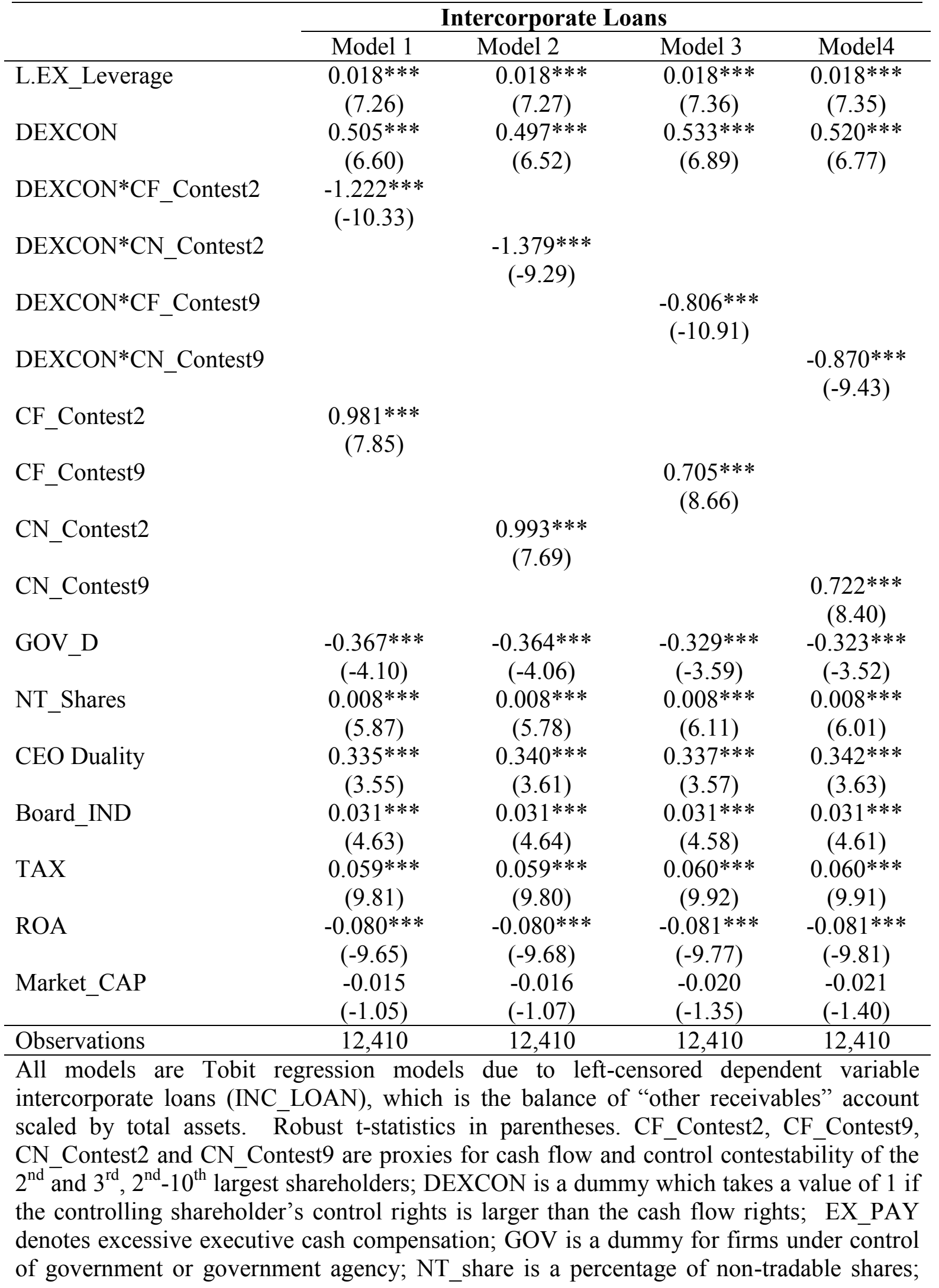


CEO Duality is a dummy if CEO is also the board Chair: Market_CAP represents is a log of market capitalisation; TAX is corporate tax rate; ROA is return on assets; $\mathrm{CF} / \mathrm{Sales}$ is operating cash flow to sales ratio; Board_IND is the percentage of independent directors

$* * * \mathrm{p}<0.01$ 
Table 8: Controlling Shareholder Excess Control Rights, Multiple Large Shareholders and Capital Investment

\begin{tabular}{|c|c|c|c|c|}
\hline & Model 1 & Model 2 & Model 3 & Model 4 \\
\hline EX_Leverage & $\begin{array}{c}-0.045^{* *} \\
(-2.48)\end{array}$ & $\begin{array}{c}-0.054 * * * \\
(-3.08)\end{array}$ & $\begin{array}{c}-0.041 * * \\
(-2.23)\end{array}$ & $\begin{array}{c}0.050^{* * * *} \\
(-2.75)\end{array}$ \\
\hline DEXCON*CF_Contest 2 & $\begin{array}{c}1.486^{*} \\
(1.78)\end{array}$ & & & \\
\hline DEXCON*CN_Contest 2 & & $\begin{array}{c}2.911 * * \\
(2.25)\end{array}$ & & \\
\hline DEXCON*CF_Contest9 & & & $\begin{array}{l}0.817 \\
(1.55)\end{array}$ & \\
\hline DEXCON*CN_Contest9 & & & & $\begin{array}{c}1.864 * * \\
(2.36)\end{array}$ \\
\hline DEXCON & $\begin{array}{l}-0.366 \\
(-0.82)\end{array}$ & $\begin{array}{l}-0.718 \\
(-1.23)\end{array}$ & $\begin{array}{l}-0.332 \\
(-0.75)\end{array}$ & $\begin{array}{l}-0.713 \\
(-1.23)\end{array}$ \\
\hline CF_Contest2 & $\begin{array}{l}-0.157 \\
(-0.28)\end{array}$ & & & \\
\hline CN_Contest 2 & & & $\begin{array}{l}0.155 \\
(0.42)\end{array}$ & \\
\hline CF_Contest 9 & & $\begin{array}{l}-0.114 \\
(-0.21)\end{array}$ & & \\
\hline CN_Contest 9 & & & & $\begin{array}{l}0.157 \\
(0.45)\end{array}$ \\
\hline GOV_D & $\begin{array}{c}0.903 * * * \\
(2.92)\end{array}$ & $\begin{array}{c}0.732 * * \\
(2.36)\end{array}$ & $\begin{array}{c}0.943 * * * \\
(3.09)\end{array}$ & $\begin{array}{c}0.698 * * \\
(2.26)\end{array}$ \\
\hline Market_CAP & $\begin{array}{l}-0.210 \\
(-1.05)\end{array}$ & $\begin{array}{l}-0.157 \\
(-0.74)\end{array}$ & $\begin{array}{l}-0.188 \\
(-0.94)\end{array}$ & $\begin{array}{l}-0.059 \\
(-0.28)\end{array}$ \\
\hline NT_Shares & $\begin{array}{c}0.020^{* * *} * \\
(4.49)\end{array}$ & $\begin{array}{c}0.022 * * * \\
(4.68)\end{array}$ & $\begin{array}{c}0.021 * * * \\
(4.61)\end{array}$ & $\begin{array}{c}0.023^{* * * *} \\
(4.82)\end{array}$ \\
\hline CEO Duality & $\begin{array}{c}0.268 \\
(0.64)\end{array}$ & $\begin{array}{l}0.212 \\
(0.51)\end{array}$ & $\begin{array}{c}0.251 \\
(0.61)\end{array}$ & $\begin{array}{l}0.129 \\
(0.31)\end{array}$ \\
\hline Board_IND & $\begin{array}{l}-0.012 \\
(-0.47)\end{array}$ & $\begin{array}{l}-0.025 \\
(-0.89)\end{array}$ & $\begin{array}{l}-0.010 \\
(-0.38)\end{array}$ & $\begin{array}{l}-0.028 \\
(-0.99)\end{array}$ \\
\hline ROA & $\begin{array}{c}0.079 * * * \\
(4.12)\end{array}$ & $\begin{array}{c}0.075^{* * *} * \\
(3.75)\end{array}$ & $\begin{array}{c}0.078 * * * \\
(4.01)\end{array}$ & $\begin{array}{c}0.071^{* * * *} \\
\quad(3.52)\end{array}$ \\
\hline Investment & $\begin{array}{c}0.385 * * * \\
(16.90)\end{array}$ & $\begin{array}{c}0.388 * * * \\
(16.98)\end{array}$ & $\begin{array}{c}0.384 * * * \\
(16.69)\end{array}$ & $\begin{array}{c}0.386^{* * *} \\
(16.68) \\
\end{array}$ \\
\hline Observations & 11,719 & 11,068 & 11,719 & 11,068 \\
\hline Number of Firms & 2,157 & 2,139 & 2,157 & 2,139 \\
\hline $\operatorname{AR}(2)$ & 0.24 & 0.46 & 0.24 & 0.47 \\
\hline Sargan & 0.31 & 0.33 & 0.37 & 0.38 \\
\hline
\end{tabular}

The dependent variable is capital investment scaled by the lagged total assets. We use the two-step dynamic panel-data system estimator with bias-corrected robust standard errors in all models; t-statistics in parentheses. INC_LOAN is a proxy for intercorporate loans; CF_Contest2, CF_Contest9, CN_Contest 2 and CN_Contest9 are proxies for cash flow and control contestability of the $2^{\text {nd }}$ and $3^{\text {rd }}, 2^{\text {nd }}-10^{\text {th }}$ largest shareholders; DEXCON is a dummy which takes the value of 1 if the controlling shareholder's control 
rights is larger than the cash flow right; EX_PAY denotes excessive executive cash compensation; GOV is a dummy for firms under control of government or government agency; NT_share is a percentage of non-tradable shares; CEO Duality is a dummy if CEO is also the board Chair: Market_CAP represents is a log of market capitalisation; $\mathrm{TAX}$ is corporate tax rate; ROA is return on assets; $\mathrm{CF} / \mathrm{Sales}$ is operating cash flow to sales ratio; Board_IND is the percentage of independent directors; Investment is capital investment.

$* * * \mathrm{p}<0.01$

$* * \mathrm{p}<0.05$

$* \mathrm{p}<0.1$. 
Appendix A: Measurement of Variables

\begin{tabular}{|c|c|}
\hline Variable & Definition \\
\hline Leverage & $\begin{array}{l}\text { The market value based financial leverage percentage ratio which equals } \\
\text { to the book value of debt divided by the total of market capitalization } \\
\text { and book value of debt. }\end{array}$ \\
\hline EX_Leverage & $\begin{array}{l}\text { The industry median adjusted excess financial leverage ratio, calculated } \\
\text { as the firm leverage ratio (LEV) minus the industry median ratio. }\end{array}$ \\
\hline INC_LOAN & $\begin{array}{l}\text { A proxy for intercorporate loans, calculated as the balance of "other } \\
\text { receivables" account scaled by total assets. }\end{array}$ \\
\hline CF_Rights1 & $\begin{array}{l}\text { The cashflow rights of the controlling shareholder, measured by the } \\
\text { percentage stock ownership. }\end{array}$ \\
\hline CN_Rights1 & The control rights of the controlling shareholder. \\
\hline CF_Rights2 & $\begin{array}{l}\text { The total of cashflow rights (percentage shareholding) of the } 2 \text { nd and } \\
\text { 3rd largest shareholders. }\end{array}$ \\
\hline CF_Rights9 & $\begin{array}{l}\text { The total of cashflow rights (percentage shareholding) of the } 2 \text { nd to the } \\
\text { 10th largest shareholders. }\end{array}$ \\
\hline CF_Contest 2 & $\begin{array}{l}\text { Cashflow rights contestability of the } 2 \text { nd and } 3 \text { rd largest shareholders } \\
\text { calculated as the ratio of CFR } 2 \text { to CFR } 1 \text {. }\end{array}$ \\
\hline CF_Contest9 & $\begin{array}{l}\text { Cashflow rights contestability of the } 2 \text { nd to the } 10 \text { th largest shareholders } \\
\text { calculated as the ratio of CFR9 to CFR1. }\end{array}$ \\
\hline CN_Contest2 & $\begin{array}{l}\text { Control rights contestability of the } 2 \text { nd and } 3 \text { rd largest shareholders } \\
\text { calculated as the ratio of CFR } 2 \text { to CNR } 1 \text {. }\end{array}$ \\
\hline CN_Contest9 & $\begin{array}{l}\text { Control rights contestability of the } 2 \text { nd to the } 10 \text { th largest shareholders } \\
\text { calculated as the ratio of CFR } 2 \text { to CNR } 1 \text {. }\end{array}$ \\
\hline DEXCON & $\begin{array}{l}\text { A dummy equals to } 1 \text { if the controlling shareholder's control rights } \\
(\mathrm{CNR} 1) \text { is larger than the cashflow rights (CFR1) and } 0 \text { if otherwise. }\end{array}$ \\
\hline EXPAY & $\begin{array}{l}\text { The excessive executive cash compensation adjusted for market } \\
\text { capitalization, ROA, GOV, and industry, calculated as the regression } \\
\text { error from an OLS regression of the average top } 3 \text { executive cash } \\
\text { compensation per person on these determinants. }\end{array}$ \\
\hline GOV & $\begin{array}{l}\text { A dummy which equals to } 1 \text { if the firm is under control of the } \\
\text { government or government agency, and } 0 \text { if otherwise. }\end{array}$ \\
\hline NT_Shares & The percentage of non-tradable shares. \\
\hline CEO Duality & $\begin{array}{l}\text { A dummy which equals to } 1 \text { if the CEO is also the Chair of the board, } \\
\text { and } 0 \text { if otherwise. }\end{array}$ \\
\hline Market_CAP & The log of market capitalization of all common shares in RMB. \\
\hline ROA & The return on assets ratio. \\
\hline TAX & The corporate tax rate. \\
\hline $\mathrm{CF} /$ Sales & The operating cashflow to sales ratio. \\
\hline Board IND & The percentage of directors who are independent. \\
\hline Investment & The capital investment scaled by the lagged total assets. \\
\hline
\end{tabular}


${ }^{i}$ As we used listed firms, market value of equity appears more relevant in the estimation of leverage. However, we checked the robustness of our results using book values as well. The results are similar and to conserve space and avoid repetition, we report the results using market values.

ii In identifying the controlling shareholder, we follow CSRC's definition of the "ultimate owner" of a publicly listed company as: (1) the largest shareholder, or (2) the shareholder with more voting power than the largest shareholder, or (3) the shareholder with shareholding or voting rights above $30 \%$ of the total shares, or voting rights in the company, or (4) the shareholder who can determine over half of the board members. This is consistent with the extensive prior literature such as Jiang et al. (2010); Liu and Tian (2012); and Liao et al. (2014).

${ }^{\text {iii }}$ Data on the voting rights of the non-controlling multiple large shareholders are unavailable; hence, the control contestability ratios are calculated using collective shareholdings of the multiple large shareholders and the control rights of the controlling shareholder.

\section{REFERENCES}

Anderson, R. \& Reeb, D. 2004. Board composition: Balancing family influence in S\&P 500 firms, Administrative Science Quarterly, 49(2): 209-237.

Allen, F., Qian, J. \& Qian, M. 2005. Law, finance, and economic growth in China, Journal of Financial Economics 77: 57-116.

Arellano, M., \& Bover. O. 1995. Another look at the instrumental variable estimation of error-components models, Journal of Econometrics, 68: 29-51.

Blundell, R \& Bond, S. 1998. Initial conditions and moment restrictions in dynamic panel data model, Journal of Econometrics, 87: 115-143.

Attig, N., Guedhami, O. \& Mishra, D. 2008. Multiple large shareholders, control contests and implied cost of equity, Journal of Corporate Finance, 14: 721-737.

Attig, N., El Ghoul, S. \& Guedhami, O. 2009. Do multiple large shareholders play a corporate governance role? Evidence from East Asia, Journal of Financial Research, 32 (4): 395-422. 
Attig, N., El Ghoul, S. \& Guedhami, O. 2013. The governance role of multiple large shareholders: evidence from the valuation of cash holding, Journal of Management and Governance, 17:419-451.

Berger P.G, Ofek E \& Yermarck D. L. 1997. Managerial entrenchment and capital structure decisions, Journal of Finance, 52(4): 1411-1438.

Berglof, E. \& Pajuste, A. 2003. Emerging owners, eclipsing market? Corporate governance in Central and Eastern Europe. In P.K. Cornelius \& B. Kogut (Eds.). Corporate governance and capital flows in a global economy, Oxford: Oxford University Press.

Bennedsen, M. \& Wolfenzon, D. 2000. The balance of power in closely held corporations, Journal of Financial Economics, 58:113-139.

Buchuk, D., Larrain, B., Muñoz, F., \& Urzúa, I. F. 2014. The internal capital markets of business groups: Evidence from intra-group loans, Journal of Financial Economics, 112, $190-212$.

Casado, R. B, Burkert, M, Davila, A. \& Oyon, D. 2016. Shareholder Protection: The Role of Multiple Large Shareholders, Corporate Governance: An International Review, 24(2): 105129.

Chang, Y-K, Chou, R.K. \& Huang, T-H. 2014. Corporate governance and the dynamics of capital structure: New evidence, Journal of Banking \& Finance, 48: 374-385.

Cheung, Y., Jing, L., Rau, R., \& Stoutaitis, A. 2006. Tunneling, propping, and expropriation: evidence from connected party transactions in Hong Kong, Journal of Financial Economics, 82: 343-386.

Claessens, S., Djankov, S., Fan, J. \& Lang, L. 2002. Disentangling the incentive and entrenchment of large shareholdings, Journal of Finance, 57 (6): 2741-2771.

Claessens, S., Djankov, S. \& Lang, L. 2000. The separation of ownership and control in East Asian corporations, Journal of Financial Economics, 58: 81-112.

Cull, R., Li, W., Sun, B., \& Xu, L. C. 2015. Government connections and financial constraints:

Evidence from a large representative sample of Chinese firms, Journal of Corporate Finance, 32: 271-294.

Dharwadkar, R., George, G. \& Brandes, P. 2000. Privatization in emerging economies: an agency theory perspective, Academy of Management Review, 25, 650-69.

Djankov, S., La Porta, R., Lopez-de-Silanes, F., \& Shleifer, A. 2008. The law and economics of self-dealing. Journal of Financial Economics, 88: 430-465.

Faccio, M. 2010. Difference between politically connected and non-connected firms: A cross country analysis, Financial Management, 39 (3): 905-928. 
Faccio, M., Lang, L.H.P. \& Young, L. 2010. Pyramiding vs. leverage in corporate groups: international evidence, Journal of International Business Studies, 41: 88-104.

Faccio, M \& Lang, L.H.P. 2002. The ultimate ownership of Western European corporations. Journal of Financial Economics, 65(3): 365-395.

Faccio, M. Lang, L. \& Young, L. 2001. Dividends and expropriation, American Economic Review, 91: 54-78.

Fan, J P.H., Wei, K.C.J \& Xu, X. 2011. Corporate finance and governance in emerging markets: A selective review and an agenda for future research, Journal of Corporate Finance, 17(2):207-214.

Firth, M., Lin, C., \& Zou, H. 2010. Friend or Foe? The Role of State and Mutual Fund Ownership in the Split Share Structure Reform in China. Journal of Financial and Quantitative Analysis, 45 (3): 685-706.

Friedman, E., Johnson, S. \& Milton, T. 2003. Propping and tunneling, Journal of Comparative Economics, 31, 732-750.

Gedajlovic, E. R., Lubatkin, M. H. \& Schulze, W. S. 2004. Crossing the threshold from founder management to professional management: A governance perspective, Journal of Management Studies, 41: 988-12.

Gomes, A. \& Novaes, W. 2005. Sharing of control versus monitoring as corporate governance mechanism, PIER Working Paper No. 01-029, University of Pennsylvania. Available at SSRN:http://ssrn.com/abstract=277111.

Guedhami, O. \& Mishra, D. 2009. Excess control, corporate governance, and implied cost of equity: International evidence, Financial Review, 44: 489-524.

Gutierrez, L.H. \& Pombo, C. 2009. Corporate ownership and control contestability in emerging markets: The case of Colombia, Journal of Economics and Business, 61: 112-139.

Jameson, M., Prevost, A. \& Puthenpurackai, J. 2015. Controlling shareholders, board structure, and firm performance: Evidence from India, Journal of Corporate Finance, 27: 120 .

Jensen, M., \& Meckling, W. 1976. Theory of the firm: managerial behavior, agency costs, and ownership structure, Journal of Financial Economics, 3: 305-360.

Jiang, G, Lee, C.M.C \& Yue, H. 2010. Tunneling through intercorporate loans: The China experience. Journal of Financial Economics, 98: 1-20.

Jiang, Y. \& Peng, M.W. 2011. Principal-principal conflicts during crisis, Asia Pacific Journal of Management, 28(4): 683-695. 
Jiang, G., Rao, P., \& Yue, H. 2015. Tunneling through Non-Operational Fund Occupancy: An investigation based on officially identified activities, Journal of Corporate Finance, 32: 295311

Jiang, F \& Kim, K.A. 2015. Corporate governance in China: A modern perspective, Journal of Corporate Finance, 32:190-216.

Kahn, C. \& Winton, A. 1998. Ownership structure, speculation, and shareholder intervention. Journal of Finance, 53:99-129.

Kumar, P. and Zattoni, A. 2014. Large shareholders and corporate governance outside the United States and United Kingdom, Corporate Governance: An International Review, 22: 294-294

La Porta, R., Lopez-De-Silanes, F., \& Shleifer, A. 1999. Corporate ownership around the world. Journal of Finance, 54: 471-517.

La Porta, R., Lopez-de-Silanes, F., Shleifer, A. \& Vishny, R. 2002. Investor protection and corporate valuation, Journal of Finance, 57: 1147-70.

Laeven, L., \& Levine, R. 2008. Complex ownership structures and corporate valuations, Review of Financial Studies, 21: 579-604.

Lehman, E. \& Weigand, J. 2000. Does the governed corporation perform better? Governance structures and corporate performance in Germany. European Finance Review, 4: 157-195.

Li, K., Lu, L., Mittoo, U.R. \& Zhang, Z. 2015. Board independence, ownership concentration and corporate performance - Chinese evidence, International Review of Financial Analysis, 41: 162-175.

Liao, L., Liu, B., \& Wang, H. 2014. China's secondary privatization: Perspectives from the Split-Share Structure Reform, Journal of Financial Economics, 113: 500-518.

Lins, K.V. 2003. Equity ownership and firm value in emerging markets, Journal of Financial and Quantitative Analysis, 38: 159-184.

Lin, C., Ma, Y., Malatesta, P., \& Xuan, Y. 2011. Ownership structure and the cost of corporate borrowing, Journal of Financial Economics, 100, 1-23.

Liu, Q. \& Tian G. (2012). Controlling shareholder, expropriations and firm's leverage decision: Evidence from Chinese non-tradable share reform, Journal of Corporate Finance, 18: $782-803$.

Luo, J. H., Wan, D. F., \& Cai, D. 2012. The private benefits of control in Chinese listed firms: Do cash flow rights always reduce controlling shareholders' tunneling? Asia Pacific Journal of Management, 29(2): 449-518. 
Mishra, D.R. 2011. Multiple large shareholders and corporate risk taking: Evidence from East Asia, Corporate Governance: An International Review, 19:507-528.

Modigliani, F \& Miller, M. 1958. The cost of capital, corporation finance and the theory of investment, American Economic Review, 48: 261-297.

Morck, R., Wolfenzon, D. \& Yeung, B. 2005. Corporate governance, economic entrenchment, and growth, Journal of Economic Literature, 43(3): 655-720.

Maury, B. \& Pajuste, A. 2005. Multiple large shareholders and firm value, Journal of Banking and Finance, 29:1813-1834.

Morch, R., Shleifer, A \& Vishny, R. 1988. Management ownership and market valuation: An empirical analysis, Journal of Financial Economics, 20: 293-315.

Pagano, M. \& Roell, A. 1998. The choice of stock ownership structure, monitoring and the decision to go public, Quarterly Journal of Economics, 113:187-225

Paligorova, T. \& Xu, Z. 2012. Complex ownership and capital structure, Journal of Corporate Finance, 18: 701-716.

Peng, M.W. \& Jiang, Y. 2010. Institutions behind family ownership and control in large firms, Journal of Management Studies, 47(2): 253-273.

Peng, W.Q., Wei, K.C.L \& Yang, Z. 2010. Tunneling or propping: evidence from connected transaction in China, Journal of Corporate Finance, 17:306-325.

Poncet, S., Steingress, W., \& Vandenbussche, H. 2010. Financial constraints in China: firmlevel evidence. China Economic Review, 21: 411-422.

Qian, M., \&Yeung, B. 2015. Bank financing and corporate governance, Journal of Corporate Finance, 32: 258-270.

Shevlin, T., Tang, T., \& Wilson, R. 2012. Domestic income shifting by Chinese listed firms, Journal of American Tax Association, 34: 1-29.

Shleifer, A. \& Vishny, R. 1997. A survey of corporate governance, Journal of Finance, 52: 737-783.

$\mathrm{Su}$, Y., Xu, D \& Plan, P.H. 2008. Principal-Principal Conflict in the Governance of the Chinese Public Corporation, Management and Organisation Review, 4 (1): 17-38.

Sun, Q., Tong, W.H.S. \& Tong, J. 2002. How does Ownership affect Firm Performance? Evidence from China's Privatisation Experience, Journal of Business Finance and Accounting, 29 (1/2): 1-27.

Sun, Q., \& Tong, W.H.S. 2003. China share issue privatization: the extent of its success, Journal of Financial Economics, 70: 183-222. 
Windmeijer, F. 2005. A finite sample correction for the variance of linear efficient two-step GMM estimators, Journal of Econometrics, 126: 25-51.

Wintoki M, Linck J. \& Netter J. 2012. Endogeneity and the dynamics of internal corporate governance, Journal of Financial Economics, 105(3): 581-606.

Wright, M., Filatotchev, I, Hoskinsson, R.E. \& Peng, M.W. 2005. Strategy research in emerging economies: challenging the conventional wisdom, Journal of Management Studies, 42: 1-33.

Young, M.N., Peng, M.W, Ahlstrom, D., Bruton, G.D \& Jiang, Y. 2008. Corporate governance in Emerging Economies: A Review of the Principal-Principal perspectives, Journal of Management Studies, 45: 197-220.

Zhang, M., Gao, S., Guan, X. \& Jiang, F. 2014. Controlling Shareholder-Manager Collusion and Tunneling: Evidence from China, Corporate Governance: An International Review, 22(6): 440-459.

Zwiebel, J. 1995. Block investment and partial benefits of corporate control, Review of Economic Studies, 62: 161-185.

Agyenim Boateng is Professor of Finance \& Banking at the Glasgow Caledonian University, UK. He earned his PhD from the University of Leeds, UK. His research interests are in the area of corporate finance, firm governance and bank risk-taking. He has published over 40 articles in a number of international journals including: International Journal of Accounting, International Review of Financial Analysis, Review of Quantitative Finance \& Accounting, Journal of International Financial Markets, Institutions \& Money and International Business Review. His research has won a number of awards including: Emerald Citations of Excellence Award, 2015; and 2013 Elsevier Best Paper Award.

Wei Huang is an Assistant Professor of Finance in The University of Nottingham's China campus located in Ningbo. He has a $\mathrm{PhD}$ in Finance from the University of Bristol, and a Financial Risk Manager designation. Wei's research interest lies in the areas of corporate finance and corporate governance in China. He has supervised a number of PhD students to completion in these areas and published over a dozen articles in high quality finance journals such as Journal of International Financial Markets, Institutions \& Money, Review of Quantitative Finance and Accounting, International Review of Financial Analysis, Small Business Economics, and Applied Economics. 